\title{
Intermittent Fasting for Twelve Weeks Leads to Increases in Fat Mass and Hyperinsulinemia in Young Female Wistar Rats
}

\author{
Ana Cláudia Munhoz ${ }^{1, *}$, Eloisa Aparecida Vilas-Boas ${ }^{1}$, Ana Carolina Panveloski-Costa ${ }^{1}$, \\ Jaqueline Santos Moreira Leite ${ }^{1}$, Camila Ferraz Lucena ${ }^{1}$, Patrícia Riva ${ }^{1}$, Henriette Emilio ${ }^{2}$ and \\ Angelo R. Carpinelli ${ }^{1}$ (D) \\ 1 Department of Physiology and Biophysics, Institute of Biomedical Sciences, University of Sao Paulo, \\ 1524 Professor Lineu Prestes avenue, Butanta, São Paulo 05508-900, Brazil; elovilasboas@usp.br (E.A.V.-B.); \\ anakpan@gmail.com (A.C.P.-C.); jaqueline.leite@usp.br (J.S.M.L.); cflucena07@gmail.com (C.F.L.); \\ patricia.riva@gmail.com (P.R.); angelo@icb.usp.br (A.R.C.) \\ 2 Department of General Biology, Ponta Grossa State University, 4748 General Carlos Cavalcanti avenue, \\ Uvaranas, Parana, PR 84030-900, Brazil; henry.emilio@gmail.com \\ * Correspondence: anamunoz@icb.usp.br; Tel.: +55-11-98-755-9099
}

Received: 29 February 2020; Accepted: 6 April 2020; Published: 9 April 2020

check for updates

\begin{abstract}
Fasting is known to cause physiological changes in the endocrine pancreas, including decreased insulin secretion and increased reactive oxygen species (ROS) production. However, there is no consensus about the long-term effects of intermittent fasting (IF), which can involve up to 24 hours of fasting interspersed with normal feeding days. In the present study, we analyzed the effects of alternate-day IF for 12 weeks in a developing and healthy organism. Female 30-day-old Wistar rats were randomly divided into two groups: control, with free access to standard rodent chow; and IF, subjected to 24-hour fasts intercalated with 24-hours of free access to the same chow. Alternate-day IF decreased weight gain and food intake. Surprisingly, IF also elevated plasma insulin concentrations, both at baseline and after glucose administration collected during oGTT. After 12 weeks of dietary intervention, pancreatic islets displayed increased ROS production and apoptosis. Despite their lower body weight, IF animals had increased fat reserves and decreased muscle mass. Taken together, these findings suggest that alternate-day IF promote $\beta$-cell dysfunction, especially in developing animals. More long-term research is necessary to define the best IF protocol to reduce side effects.
\end{abstract}

Keywords: intermittent fasting; fat mass; insulin secretion; pancreatic islet

\section{Introduction}

The increasing prevalence of obesity around the globe is known to be linked to unhealthy eating patterns and a sedentary lifestyle. Treatments in obesity involve hypocaloric diets associated with physical exercises, producing an overall energy deficit [1,2] and leading to weight loss. One of the many diets that results in weight loss in both humans and laboratory animal models is intermittent fasting (IF). The most common IF protocols adopted by people in attempt to lose weight involve daily fasting for up to 16 hours; or fasting periods of up to 24 hours interspersed with normal feeding days [3,4]. Despite demonstrated weight loss [5-7], more studies are needed to evaluate whether alternate-day IF diets promote health benefits or could cause undesired effects in the long run.

Several studies about IF in both volunteers and animal models have uncovered beneficial effects, such as improved insulin sensitivity and glucose homeostasis [8-10]; improved performance and metabolic efficiency during exercise [11], increased alertness [12], and increased life expectancy [13-15]; 
a reduction in blood pressure and heart rate [16-20]; a reduction in inflammation; and protection against neurodegeneration [17-19,21-30].

On the other hand, many studies have reported adverse outcomes as a consequence of IF. Diabetic individuals performing IF may exhibit hypoglycaemia, ketoacidosis, dehydration, hypotension, and thrombosis [10,31]. A study in middle-aged men showed a significant increase in blood pressure and total cholesterol [32]. Increased plasma concentrations of cortisol at night have also been reported in several studies following daily fasting for one month, suggesting altered circadian rhythms [33-40]. IF may lead to the worsening of glucose tolerance in non-obese women [41] and cause decreased energy expenditure in young women [42]. Munsters et al. compared plasma insulin and glucose concentrations over only three days of reduced meal frequency and found that the intermittent fasting model produced higher peaks and more abrupt declines in insulin and glucose concentrations, indicating a biological environment prepared for long-term insulin resistance and diabetes [43].

Various physiological parameters are known to be altered in the endocrine pancreas during acute fasting, including insulin syntheses, glucose-stimulated insulin secretion (GSIS), glucose utilization, pancreatic islet metabolism, and pancreatic $\beta$-cell sensitivity to glucose [44-50]. Our group showed that a 48-hour acute fast increases net reactive oxygen species (ROS) production in isolated pancreatic islets and alters GSIS [51]. Thus, in the present study, we sought to evaluate the effects of 12 weeks of IF on glucose homeostasis and pancreatic islets isolated from rats.

\section{Material and Methods}

\subsection{Ethical Approval}

The Ethical Committee on Animal Research of the Institute of Biomedical Sciences of the University of São Paulo (CEUA) and Brazilian Society of Science in Laboratory Animals (SBCAL) approved the experimental protocols for this study, including the use of 24-hour fasted rats. The approved protocol number is 157/2014/CEUA.

\subsection{Animals}

Three-week-old female Wistar rats were transferred from the breeding facility to the experimental facility and remained 1 week for acclimatization before IF is initiated. The animals were housed in cages with three animals each in a room with constant temperature of $23 \pm 2{ }^{\circ} \mathrm{C}$ on a standard 12-hour light/dark cycle. After acclimatization, the animals were randomized into two groups: control (CT) and intermittent fasting (IF) for 12 weeks. During the treatment, the CT group had free access to the standard rodent chow (Nuvilab, Sao Paulo, SP, Brazil - macro-nutrients in supplemental Figure S1) and the IF group was submitted to periods of 24 hours of total food deprivation interspersed with periods of 24 hours of ad libitum access to the same standard rodent chow. Food was withdrawn or made available to the IF group at noon (Figure 1). Both groups had free access to water for the entire period. During the full period, body weight and food intake were recorded. During the last week of treatment, we performed an oral glucose tolerance test (oGTT), an intraperitoneal insulin tolerance test (iTTT), and dual x-ray absorptiometry. After 12 weeks of treatment, the animals were killed, and the pancreas, blood, liver, adipose tissue, and muscle were collected for different analyses. All tissue weights collected were normalized by the body weight of the animals. Euthanasia was always performed after the 24-hour period of free access to food, so that both groups were fed, thus eliminating the need to subject the control animals to acute fasting and excluding its effects. The exception occurred in liver collection, in order to analyze glycogen content after acute fasting, so, in this way, liver collection was also performed after a 24-hour fast of both groups in two different cohorts (i.e., both groups with free access to food or both groups in 24-hour fasting). 


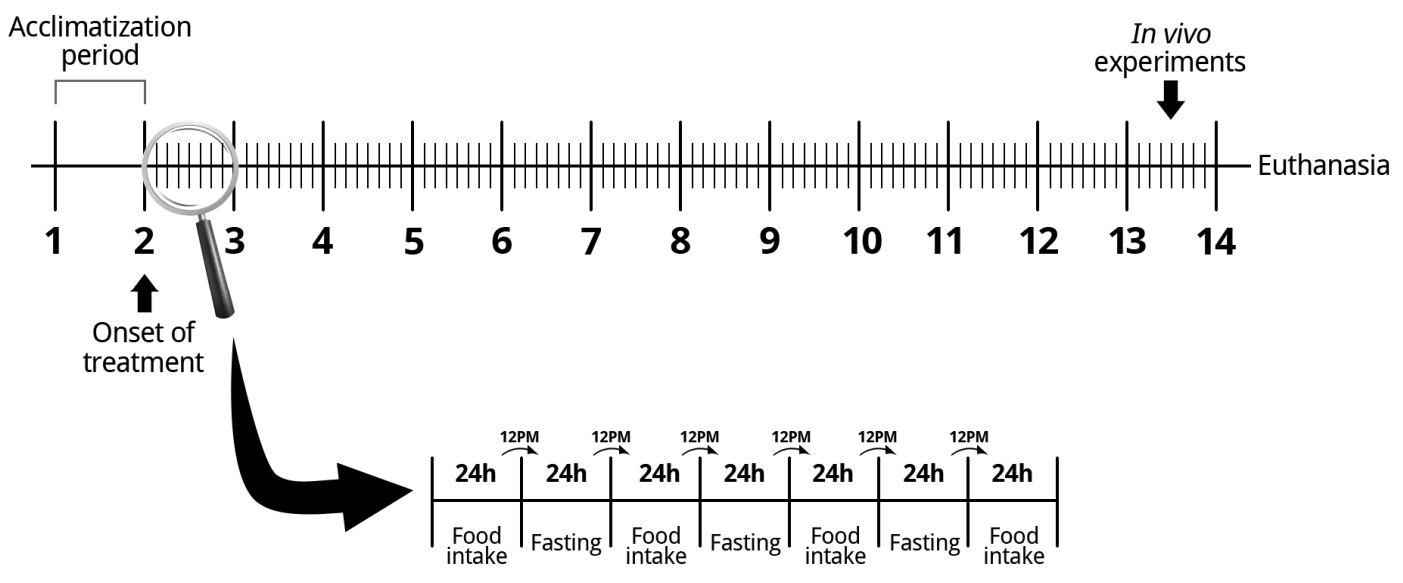

Figure 1. Scheme of the intermittent fasting protocol used.

\subsection{Indexes Calculation}

The Lee index was calculated using the body weight (grams) and naso-anal length (centimeters) of the animals. The Lee index and adipose tissue mass correlate and can be used as a simple measure of obesity in rats [52].

$$
\text { Lee index }=\frac{\sqrt[3]{\text { body weight }}}{\text { naso_anal length }}
$$

The Homeostasis Model Assessment (HOMA) index is based on fasting plasma insulin (ng/ml) and glucose concentrations $(\mathrm{mg} / \mathrm{dL})$ [53]. Its purpose is to determine insulin resistance (HOMA-IR) and the functional capacity of pancreatic $\beta$-cells (HOMA-BETA).

$$
\begin{aligned}
& \text { HOMA_IR }=\frac{(\text { Fasting plasma insulin } \times \text { Fasting blood glucose })}{22.5} \\
& \text { HOMA_BETA }=\frac{(\text { Fasting plasma insulin } \times 20)}{(\text { Fasting blood glucose }-3.5)}
\end{aligned}
$$

\subsection{Dual Energy x-Ray Absorptiometry (DEXA)}

The animals were anesthetized with Sodium Tiopental (Cristália, Itapira, SP, Brazil) at a dose of $0.2 \mathrm{U} / \mathrm{g}$ body weight and placed in a dual energy in vivo radiological absorptiometry device (Biocompare In-Vivo Imaging System FX PRO, San Francisco, CA, USA) for the quantification of abdominal adipose tissue reserves. The images captured had the regions of interest (ROI) delimited and their pixels were quantified for analysis using ImageJ software.

\subsection{Glycogen Measurement}

The liver was collected after the euthanasia of the animals at two different cohorts: after the 24-hour fasting period or after the 24-hour ad libitum food ingestion period, i.e., either the CT and IF groups with free access to food or the CT and IF groups in 24-hour fasting. In total, $250 \mathrm{~g}$ of each sample was weighed and placed in a $15-\mathrm{mL}$ conical tube. Then, $1 \mathrm{~mL}$ of $30 \%$ potassium hydroxide (Sigma-Aldrich, St Louis, MO, USA) was added to the tissues and boiled for 1 hour. After that, $100 \mu \mathrm{L}$ of saturated sodium sulfate solution (Sigma-Aldrich, St Louis, MO, USA) and $3.5 \mathrm{~mL}$ of $70 \%$ ethanol (Synth, Diadema, SP, Brazil) were added to the mixture and the samples were boiled for 15 minutes and centrifuged at 3000 RPM for 7 minutes. The supernatant was discarded and the ethanol wash was repeated. The samples were resuspended in $1 \mathrm{~mL}$ of hot water and then $50 \mu \mathrm{L}$ of the sample and $200 \mu \mathrm{L}$ of $0.2 \%$ antrona concentrated sulfuric acid solution (Sigma-Aldrich, St Louis, MO, USA) were placed in a 96-well plate. Next, absorbance at a wavelength of $650 \mathrm{~nm}$ was recorded by a plate reader (Biotek 
Sinergy H1 - Winooski, VT, USA). Glycogen concentrations were calculated using the absorbance values, and the liver mass (grams) of tissue was used to normalize glycogen concentrations.

\subsection{Oral Glucose Tolerance Test}

In the last week of treatment (12th week), both groups were submitted to a 12-hour overnight fast. Then, blood was collected by tail snip for glucose measurement (time 0 ) on a blood glucose monitor (FreeStyle Potium Neo, Witney, Oxon, Uk). Later, a glucose solution of $2 \mathrm{~g} / \mathrm{kg}$ per body weight was administered to the animals through gavage, and blood glucose concentrations were measured after 5 , $10,15,30,60,90$, and $120 \mathrm{~min}$.

\subsection{Intraperitoneal Insulin Tolerance Test}

In the last week of treatment (12th week), in a cohort different from that in which we performed oGTT, animals were submitted to a 4-hour food restriction. Then, blood was collected by puncture at the animal caudal end for glucose measurement (time 0) on a blood glucose monitor (FreeStyle Potium Neo, Witney, Oxon, UK). After that, a solution of regular human insulin (Humulin, Indianapolis, IN, USA) at a dose of $0.75 \mathrm{U} / \mathrm{kg}$ per body weight was administered to the animals by intraperitoneal injection, and blood glucose concentrations were measured after 5, 10, 15, 30, 60, 90, and $120 \mathrm{~min}$.

\subsection{Blood Analysis}

Blood was collected for insulin concentrations measurement following an Elisa kit protocol (Milipore, Billerica, MA, USA). Hemoglobin A1c (HbA1c) was also assessed by following the protocol of an automated chemistry analyzer by immunoturbidimetry (Labtest, Lagoa Santa, MG, Brazil).

\subsection{Isolation of Pancreatic Islets}

The isolation of pancreatic islets was carried out by the method of exocrine pancreas digestion using collagenase V [54], in which $20 \mathrm{~mL}$ of collagenase solution $(0.68 \mathrm{mg} / \mathrm{mL}$-Sigma-Aldrich, St. Louis, MO, USA) was injected through the bile duct. The dissected pancreas was placed in a bath at $37^{\circ} \mathrm{C}$ for $25 \mathrm{~min}$ and shaken by hand for exocrine pancreas digestion. The sample was washed to remove exocrine tissue, and pancreatic islets were collected using a micropipette and a stereoscope.

\subsection{Static Insulin Secretion}

Pancreatic islets isolated from Wistar rats were placed in a microtube containing Krebs-Henseleit buffer with $0.1 \%$ albumin and $5.6 \mathrm{mM}$ glucose for $30 \mathrm{~min}$. Next, the islets were incubated at $37{ }^{\circ} \mathrm{C}$ in a microtube containing Krebs-Henseleit with $2.8,5.6,8.3,11.1$, or $16.7 \mathrm{mM}$ glucose. Then, the supernatant and sonicated islets were stored at $-20{ }^{\circ} \mathrm{C}$ for further measurements. The amounts of secreted and intracellular insulin content were determined by radioimmunoassay (RIA) [55].

\subsection{Pancreas Histological Assessment}

The pancreas was dissected, collected, and fixed with $40 \mathrm{~mL}$ of $10 \%$ formalin. Then, the pancreases were paraffin-embedded and sectioned at $4 \mu \mathrm{m}$ using a semi-automated microtome (RM2155 Leica Micro-systems, Wetzlar, Hessen, Germany). Afterward, the tissue sections were mounted on glass slides. The sections were stained with hematoxylin and eosin (H\&E). All slides were examined using light microscopy with a camera attached (Nikon Eclipse TS100, Sao Paulo, SP, Brazil) under a magnification of X200. The slides were scanned and all pancreatic islets found were photographed. The images were calibrated and analyzed with the Aperio ImageScope software (Leica Micro-systems, Wetzlar, Hessen, Germany), then the length and width of each islet were measured. Next, the area of each pancreatic islets present on each slide was quantified by multiplying length and width. 


\subsection{Cell Viability}

For the analysis of cell viability, groups of 20 pancreatic islets were dissociated, and the cells were incubated with ViaCount reagent (Millipore, Billerica, MA, USA) for 5 minutes at room temperature. The samples were placed into a 96-well plate for flow cytometer reading (Guava easyCyte ${ }^{\mathrm{TM}} 8 \mathrm{Ht}$ Sampling - Millipore, Billerica, MA, USA), and cell viability, cell apoptosis, and cell death were quantified by counting 1000 events.

\subsection{Measurement of Net ROS Production}

Previously isolated islets were pre-incubated with Krebs-Henseleit buffer containing $5.6 \mathrm{mM}$ glucose. Next, the samples were maintained for 1 hour in Krebs-Henseleit buffer containing 2.8 or $16.7 \mathrm{mM}$ glucose. Then, the samples were incubated for $20 \mathrm{~min}$ with redox sensitive probe $50 \mu \mathrm{M}$ dihydroethidium (DHE- Life Technologies, Eugene, Oregon, EUA) or $15 \mu \mathrm{M}$ MitoSOX Red reagent (Life Technologies, Eugene, Oregon, USA $-5 \mu \mathrm{M}$ ). After that, $300 \mu \mathrm{L}$ of trypsin (Gibco, Grand Island, NY, USA) was added for 2 min to disperse the cells. Afterward, for trypsin inactivation, $600 \mu \mathrm{L}$ of RPMI-1640 culture medium with $5 \%$ fetal bovine serum was added (Life Technologies, Itapevi, SP, Brazil). The islets were recollected and homogenized in $200 \mu \mathrm{L}$ of RPMI-1640 culture medium for cell dispersion. The samples were placed in a 96-well plate and analyzed by flow cytometry (Guava EasyCyte 8HT- Millipore, Billerica, MA, USA).

\subsection{Measurement of Net Hydrogen Peroxide Production}

Groups of 120 pancreatic islets were placed in a microtube and pre-incubated for $30 \mathrm{~min}$ at $37^{\circ} \mathrm{C}$ with in Krebs-Henseleit buffer with $5.6 \mathrm{mM}$ glucose and $0.1 \%$ albumin. After this period, the islets were incubated for 1 hour at $37^{\circ} \mathrm{C}$ with 2.8 or $16.7 \mathrm{mM}$ glucose. Then, the samples were sonicated and incubated for 30 minutes with $50 \mu \mathrm{M}$ Amplex Red probe (Life Technologies, Eugene, OR, USA), a specific marker for hydrogen peroxide $\left(\mathrm{H}_{2} \mathrm{O}_{2}\right)$. The samples were placed into a 96-well plate for absorbance reading at $560 \mathrm{~nm}$ in a microplate reader (Biotek, Winooski, VT, USA).

\subsection{Western Blot Analysis}

To evaluate protein kinase B phosphorylation (p-AKT), samples of liver, retroperitoneal white adipose tissue (WAT), and extensor digitorum longus muscle were removed before and after an intravenous administration of $10 \mathrm{U}$ regular insulin (Eli Lilly and Company, Indianapolis, IN, USA). To evaluate the expression of mitochondrial superoxide dismutase (SOD2) and glutathione peroxidase 1 (GPX1), groups of 300 pancreatic islets were collected after euthanasia of the animals. The tissues were collected in radioimmunoprecipitation assay buffer (Thermo Scientific, Saint Louis, MI, USA) containing protease and phosphatase inhibitors. The samples were sonicated, laemmli buffer was added, and the samples were boiled for $5 \mathrm{~min}$. After that, polyacrylamide gel electrophoresis was performed followed by transfer to a nitrocellulose membrane. After transfer, the membranes were blocked with $5 \%$ bovine albumin solution for one hour at room temperature and incubated overnight at $4{ }^{\circ} \mathrm{C}$ with primary antibody (Millipore, Darmstadt, Hesse, Germany). They were incubated with the secondary antibody (Bio-Rad Laboratories Inc., Hercules, CA, USA) for 1 hour at room temperature. Finally, the membranes were developed using the enhanced chemiluminescent (ECL) reagent, and the images were captured by the Image Quant LAS4000 apparatus (GE Healthcare, Uppsala Sweden). The quantitative analysis of the bands was made by densitometry with the program of the Image Quant apparatus. Protein expression was normalized by the expression of the constitutive $\alpha$-tubulin protein as the control protein or through the stained membranes with Ponceau-S to control protein loading.

\subsection{Statistical Analysis}

The results are expressed as the mean \pm standard error of the mean (SEM). GraphPad Prism 5 software was used for analysis. Differences between multiple conditions were determined by One-way 
ANOVA followed by Bartlett's test for equal variances or two-way ANOVA followed by Sidak's multiple comparisons test, as specified in figure legends. In experiments with only two conditions, the differences were determined by Student's t-test. Comparisons were considered significantly different for $p<0.05$.

\section{Results}

\subsection{Body Weight Gain and Development}

Thirty-day-old Wistar rats were randomly divided into two groups: control (CT) and submitted to intermittent fasting (IF) for 12 weeks. Lower weight gain was recorded in the IF group already after the second week of dietary intervention (Figure 2A-week 3). These changes were maintained throughout the whole treatment period; the area under the curve of the treated animals was $20.3 \%$ lower than the control animals (Figure 2A). At the end of the treatment, the tibia length and naso-anal length were significantly decreased in the IF group (Figure 2B,C), and this led to an increased Lee index (Figure 2D).
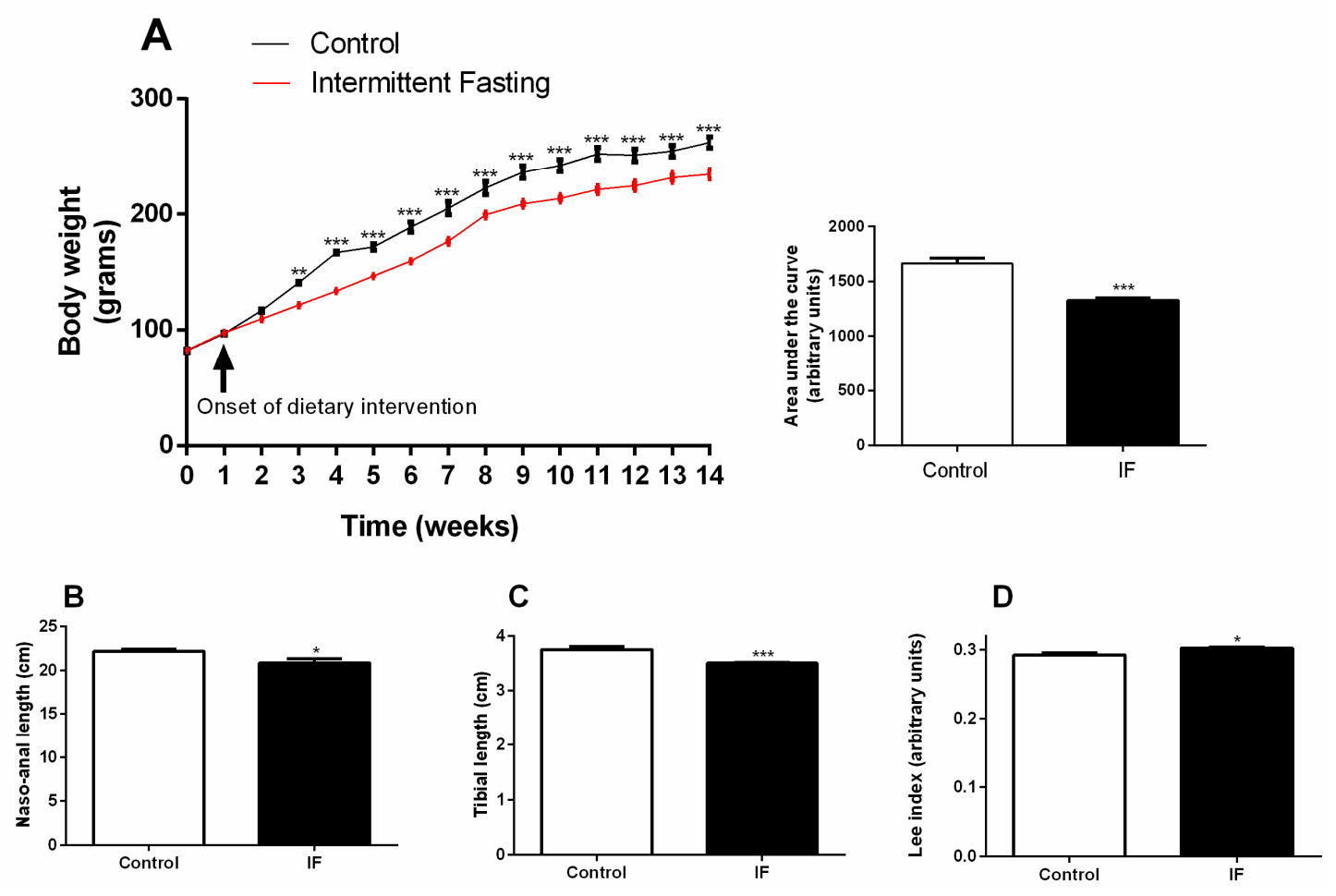

Figure 2. (A) Weekly body weight, (B) naso-anal length, (C) tibia length, and (D) the Lee index of Wistar rats submitted to intermittent fasting (IF) for 12 weeks. The results are presented as the means \pm standard error of the mean (SEM) with 10 different animals for each group. ${ }^{*} p<0.05,{ }^{* *} p<0.005$, and *** $p<0.0005$ compared to the control of the same period, as indicated by two-way ANOVA followed by Sidak's multiple comparisons test (A) or Student's t-test (B-D).

\subsection{Food Intake and Stomach Disturbances}

The IF group consumes 35\% less chow compared to the control group if the average total intake is considered, i.e., fasting days (zero consumption) plus feeding days (gorging behavior). However, if we consider only the mean ingestion of ad libitum ingestion days, the consumption in relation to the control is $31 \%$ higher, indicating chow overconsumption (Figure 3A). Figure 3B,C show that this hyperphagia caused a large increase in stomach length (by $47.95 \%$ ) and weight (by 171.66\%). Even after emptying stomach contents, we observed increased stomach weight by $12.55 \%$ (Figure 3D). 

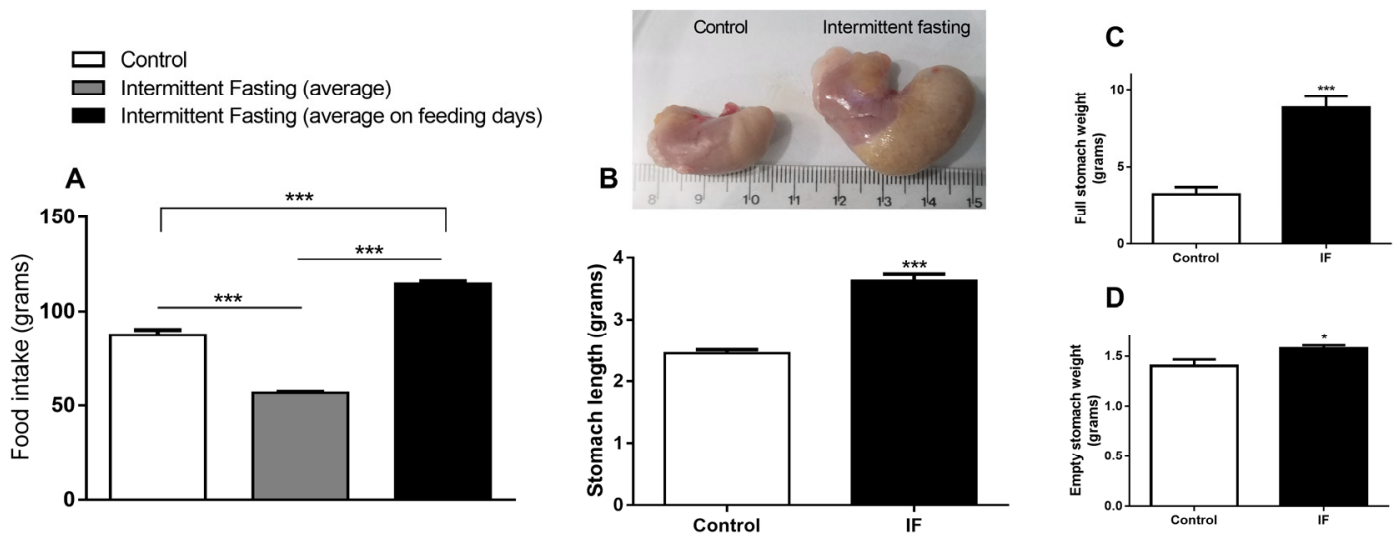

D

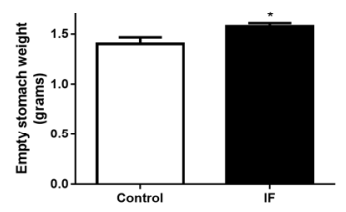

Figure 3. (A) Food intake, (B) stomach length, and (C) full and (D) empty stomach weight of Wistar rats submitted to IF for 12 weeks. The results are presented as the means \pm standard error of the mean (SEM) with 10 different animals for each group. ${ }^{*} p<0.05$ and ${ }^{* * *} p<0.0005$ compared to the control of the same period, as indicated by one-way ANOVA followed by Bartlett's test for equal variances (A) or Student's t-test.

\subsection{Body Composition}

In vivo dual energy $\mathrm{x}$-ray absorptiometry showed increased abdominal adiposity, as can be seen in Figure 4A. In addition, the weights of adipose tissues (Figure 4B-D) and dry muscles (Figure 4E-G) reveals changes in body composition with fat mass gain and muscle loss in the IF group.
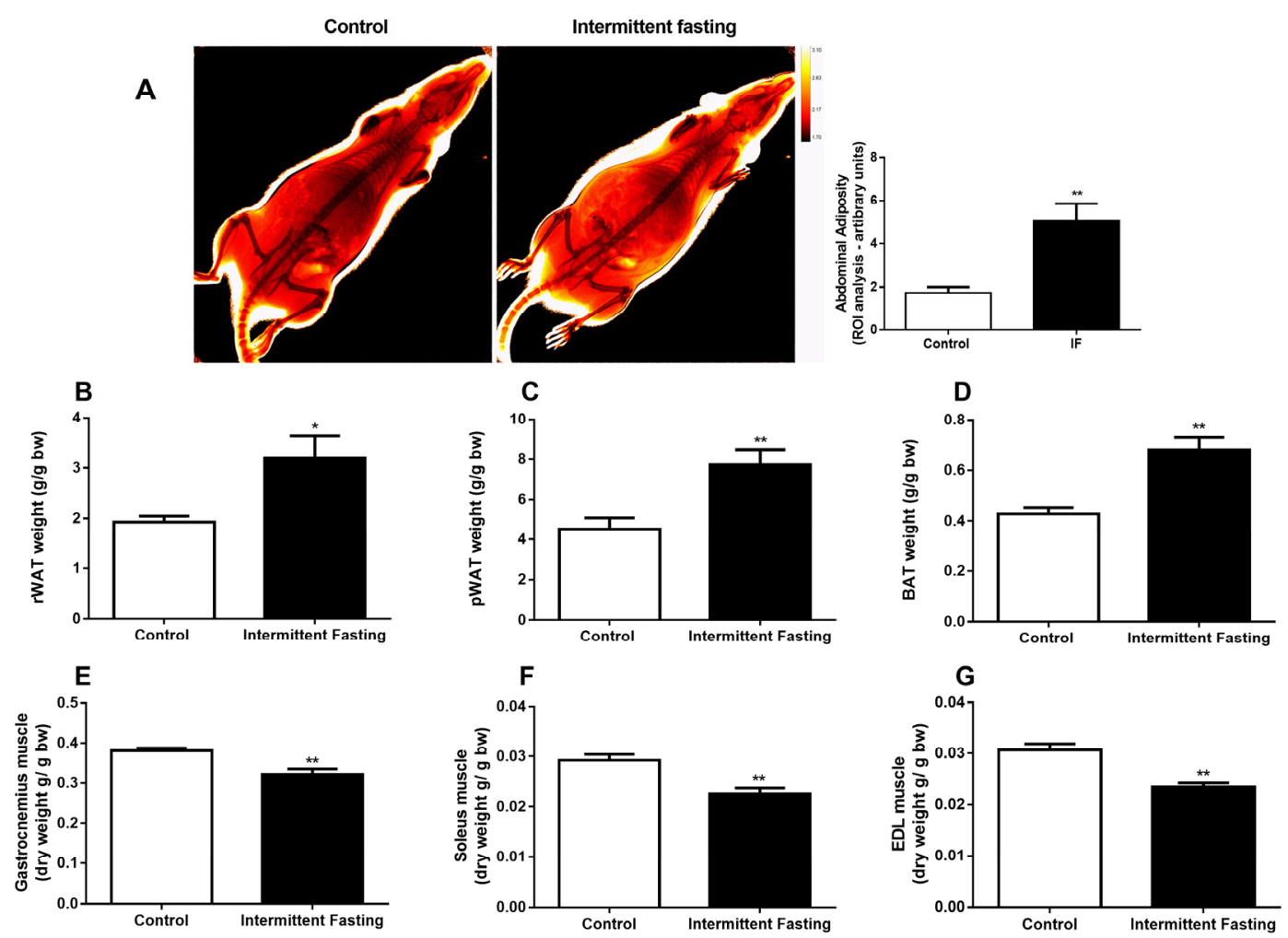

Figure 4. (A) Dual energy x-ray absorptiometry (DEXA), (B) retroperitoneal, (C) perigonadal, and (D) brown adipose tissue weight. (E) Dry gastrocnemius weight, (F) Soleus, and (G) Extensor digitorum longus (EDL) muscle of Wistar rats submitted to IF for 12 weeks. The results are presented as the means \pm standard error of the mean (SEM) with 10 different animals for each group. ${ }^{*} p<0.05$ and ${ }^{* *} p<0.005$ compared to the control of the same period, as indicated by Student's $t$-test. 


\subsection{Liver Alterations}

IF reduced liver weight in the fed state by $13.8 \%$ (Figure $5 \mathrm{~A}$ ) and after fasting by $35.68 \%$ (Figure $5 \mathrm{~B}$ ) when compared to the control in a similar state, whereas the reduction in liver weight may be correlated with reduced glycogen stores. We analyzed glycogen content in both states. In the fed state, a $47.68 \%$ reduction in glycogen (Figure 5C) was observed, and fasting led to a $98.33 \%$ liver glycogen decrease in the IF group (Figure 5D).

A
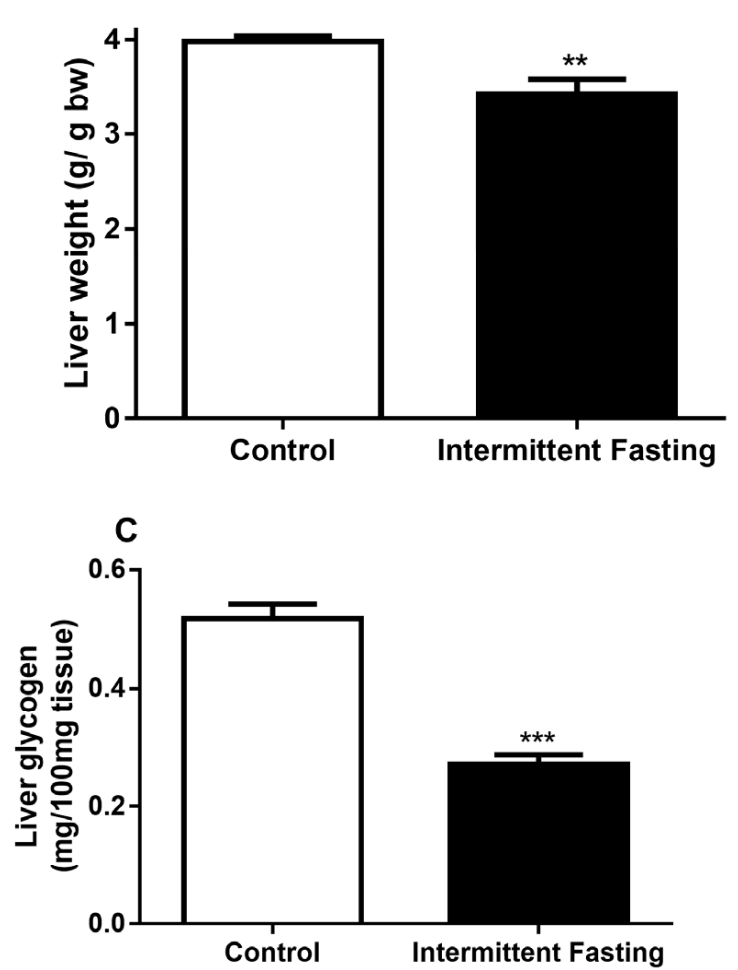

B

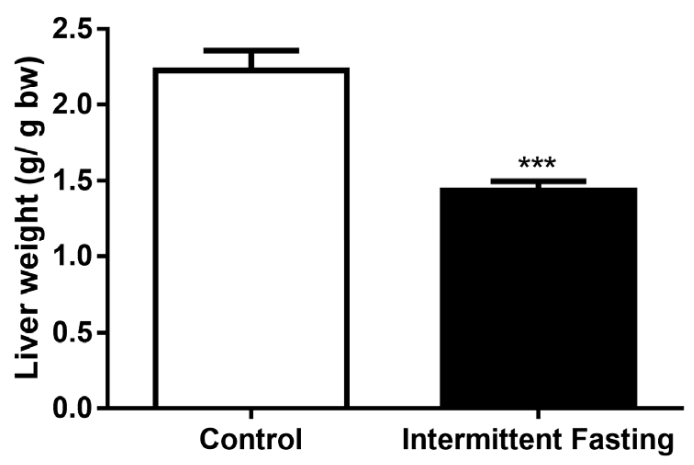

D

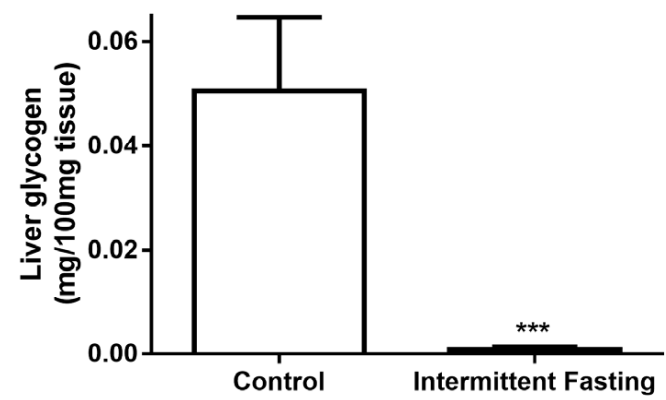

Figure 5. (A) Liver weight before and (B) after $24 \mathrm{~h}$ of fasting, (C) liver glycogen content before and D) after 24h of fasting of Wistar rats submitted to IF for 12 weeks. The results are presented as the means \pm standard error of the mean (SEM) with 10 different animals for each group. ${ }^{* *} p<0.005$ and *** $p<0.0005$ compared to the control of the same period, as indicated by Student's t-test.

\subsection{Glucose Homeostasis}

An oral glucose tolerance test (oGTT) performed at the end of treatment showed no differences between the control and IF group (Figure 6A). The area under the curve was significantly lower in this group with a reduction of $6.8 \%$ (Figure $6 \mathrm{~B}$ ). However, hemoglobin A1c levels after IF treatment do not differ significantly compared to the control group (Figure 6C).

At the end of the treatment, an intraperitoneal insulin tolerance test (iITT) was also performed. Although the area under the curve was 27\% lower in the IF group (Figure 7B), the groups did not show significant differences in blood glucose values at any of the times studied (Figure 7A) and the glucose decay constant (Kitt) did not differ between groups (Figure 7C). 

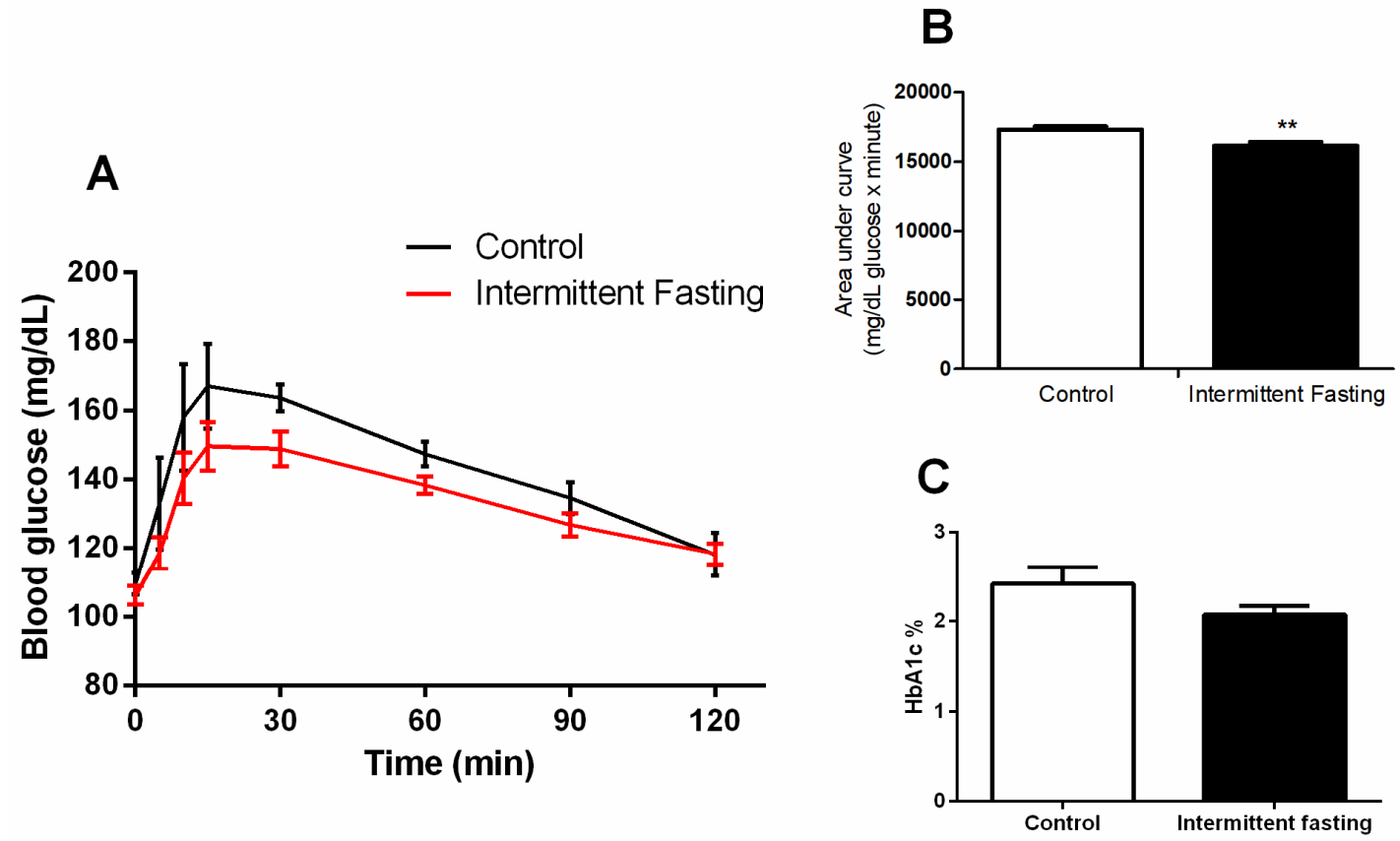

Figure 6. (A) Oral glucose tolerance test (oGTT), (B) area under curve, and (C) hemoglobin A1c (HbA1c) of Wistar rats submitted to IF for 12 weeks. The results are presented as the means \pm standard error of the mean (SEM) with 5 different animals for each group. ${ }^{* *} p<0.005$ compared to the control, as indicated by Student's t-test (B and C), two-way ANOVA followed by Sidak's multiple comparisons test (A).
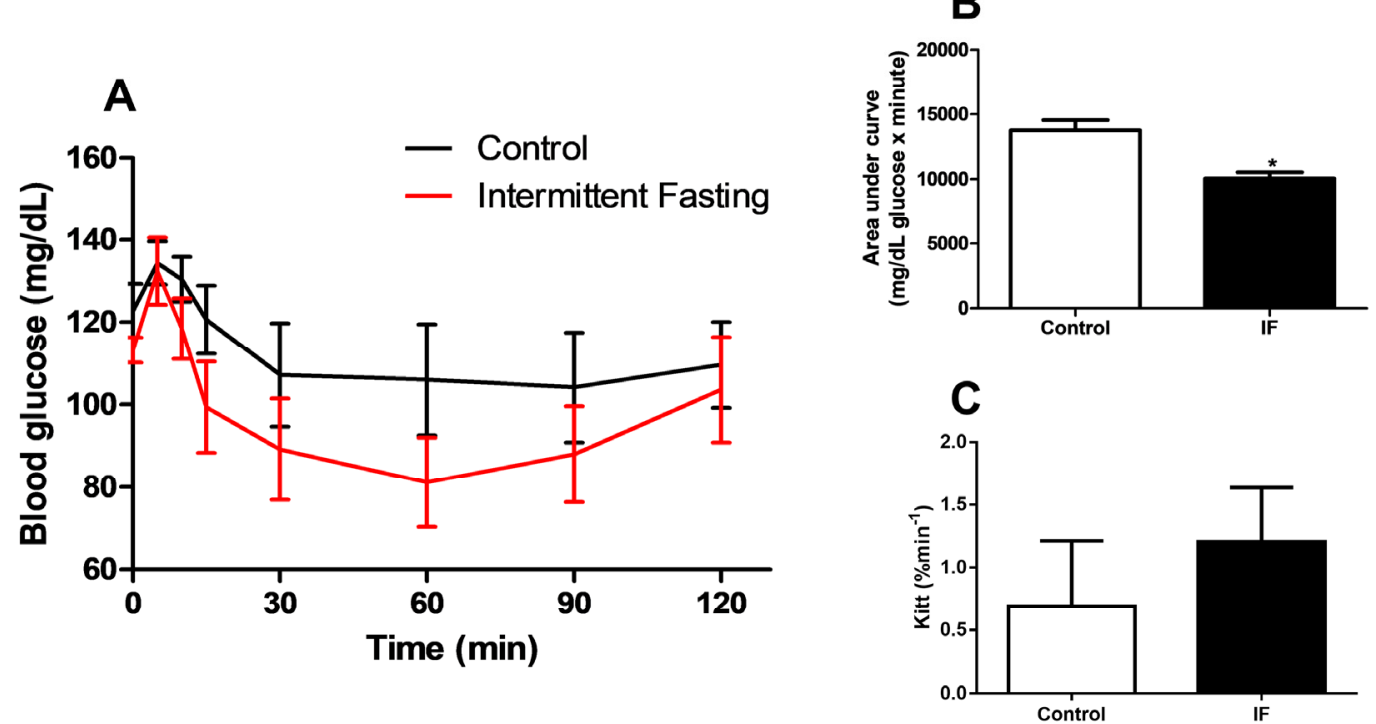

Figure 7. (A) Intraperitoneal insulin tolerance test (iITT), (B) area under curve and (C) glucose decay constant rate during insulin tolerance test (kITT) of Wistar rats submitted to IF for 12 weeks. The results are presented as means \pm standard error of the mean (SEM) with 5 different animals for each group. * $p<0.05$ compared to the control, as indicated by Student's t-test (B and C), two-way ANOVA followed by Sidak's multiple comparisons test (A).

\subsection{Insulin Concentrations}

Plasma insulin concentrations were measured in the fasted state and after 15, 30, 90, and $120 \mathrm{~min}$ of oral glucose administration. Intermittent fasting for 12 weeks greatly increased basal plasma insulin concentrations (by 4-fold). Insulin increase was also observed in the IF group by $155 \%, 271 \%, 259.7 \%$, and $304 \%$ after $15,30,90$, and 120 min of oral glucose stimulation (Figure $8 \mathrm{~A}$ ), respectively. 

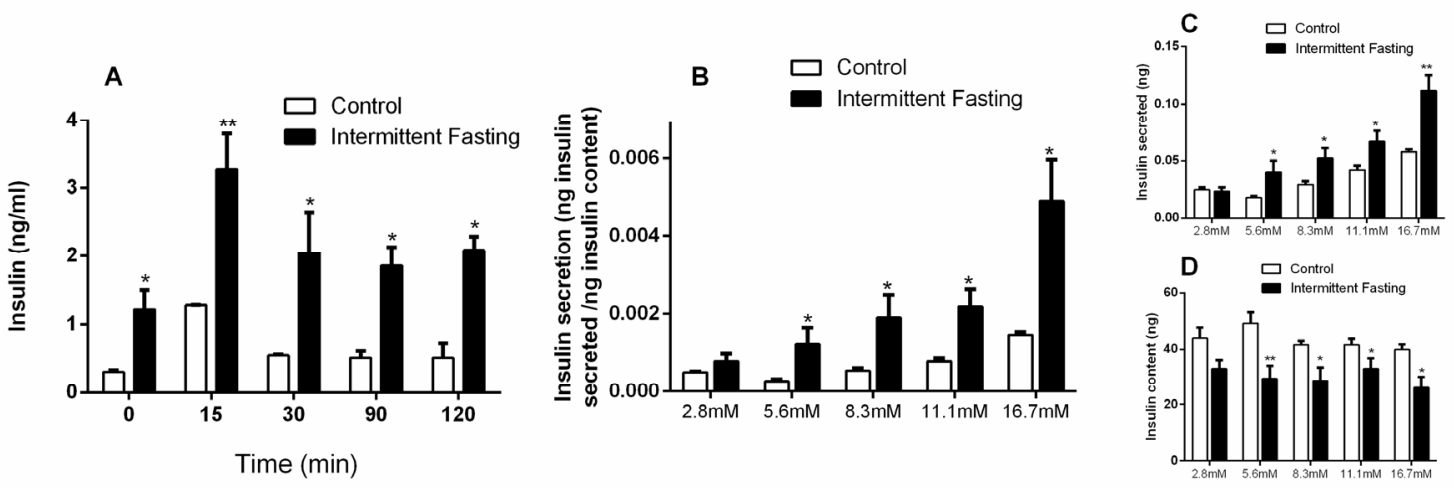

Figure 8. (A) Insulin concentrations obtained during oral glucose tolerance tests (oGTT) in Wistar rats submitted to IF for 12 weeks. (B) Content-corrected insulin secretion, (C) insulin secretion, and (D) insulin content values in pancreatic islets isolated from Wistar rats submitted to IF for 12 weeks, after one hour of incubation in the presence of 2.8, 5.6, 8.3, 11.1, and $16.7 \mathrm{mM}$ glucose. The results are presented as the means \pm standard error of the mean (SEM) with 5 different animals for each group. ${ }^{*} p<0.05$ and ${ }^{* *} p<0.005$ compared to the control at the same time, as indicated by two-way ANOVA followed by Sidak's multiple comparisons test.

A glucose-stimulated insulin secretion (GSIS) assay was performed with isolated pancreatic islets after glucose stimulation at 2.8, 5.6, 8.3, 11.1, and $16.7 \mathrm{mM}$ levels. Content-corrected GSIS and secreted insulin (Figure 8B,C) were significantly higher after intermittent fasting at all glucose concentrations, except in presence of $2.8 \mathrm{mM}$ glucose. At the same time, the insulin content remaining in the pancreatic islets of the IF group was lower at all glucose concentrations, with the exception of low-level glucose (Figure 8D), which corroborates the higher values of insulin found.

\subsection{Homeostasis Model Assessment (HOMA) Indexes}

From the values of fasting blood glucose and fasting plasma insulin, both obtained during oGTT performed in the last week of dietary intervention (time 0 - before glucose administration), we calculated HOMA-IR and HOMA- $\beta$ indexes, which are mathematical models used to evaluate insulin resistance. Intermittent fasting greatly increased values in both models by 3.6-fold (HOMA-IR) and by 4.7 -fold (HOMA- $\beta$ ), as can be observed in Figure 9A,B.

A

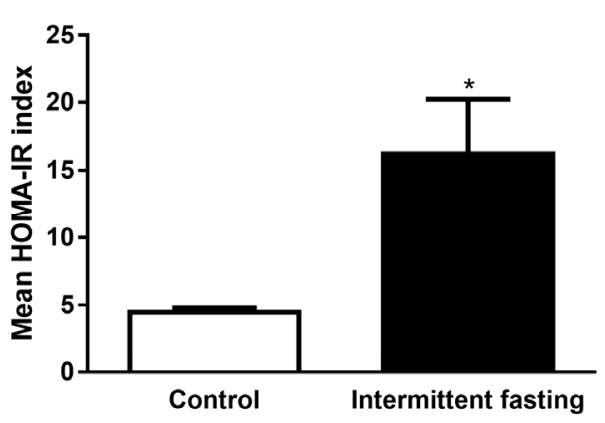

B

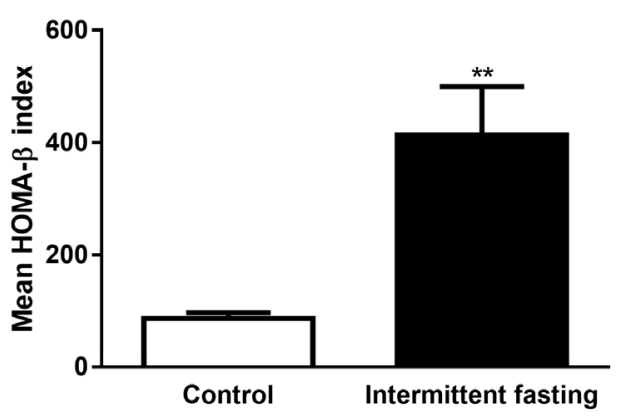

Figure 9. (A) Homeostasis model assessment of insulin resistance (HOMA-IR) and (B) homeostasis model assessment of $\beta$-cell function (HOMA- $\beta$ ) indexes of Wistar rats submitted to IF for 12 weeks. The results are presented as the mean \pm standard error of the means (SEM) with 5 different animals for each group. ${ }^{*} p<0.05$ and ${ }^{* *} p<0.005$ compared to the control, as indicated by Student's $t$-test. 


\subsection{AKT Phosphorylation}

Figure 10 shows that 12 weeks of intermittent fasting were able to alter AKT phosphorylation in muscle, liver, and white adipose tissue (WAT). In the control group, an increase in AKT phosphorylation after intravenous insulin stimulation was observed, while the IF group did not show significant differences in AKT phosphorylation, indicating impairment in insulin action (Figure 10A-C).

A
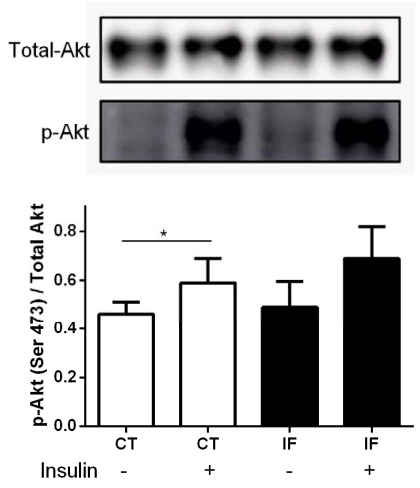

B
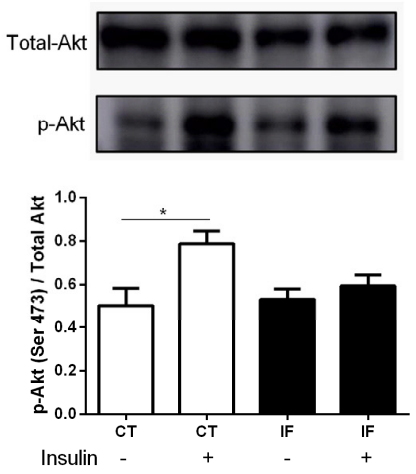

C
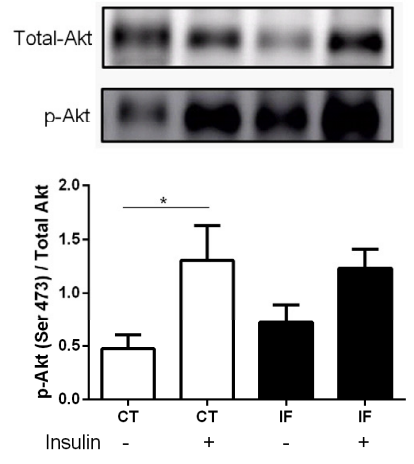

Figure 10. (A) Protein kinase B phosphorylation (p-AKT) expression of extensor digitorum longus (EDL) muscle, (B) liver, and (C) retroperitoneal white adipose tissue from Wistar rats submitted to IF for 12 weeks. The results are presented as the means \pm standard error of the mean (SEM) with 5 different preparations for each group. ${ }^{*} p<0.05$ compared to the respective control, as indicated by Student's t-test.

\subsection{Pancreatic Islet Area and Viability of Cells from Pancreatic Islets}

Histological analyzes in pancreas revealed a $28.6 \%$ decrease in the islet size of the animals submitted to IF treatment (Figure 11A,C). The weight of the pancreas also showed a significant reduction in the IF group of about $26 \%$ (Figure 11B).
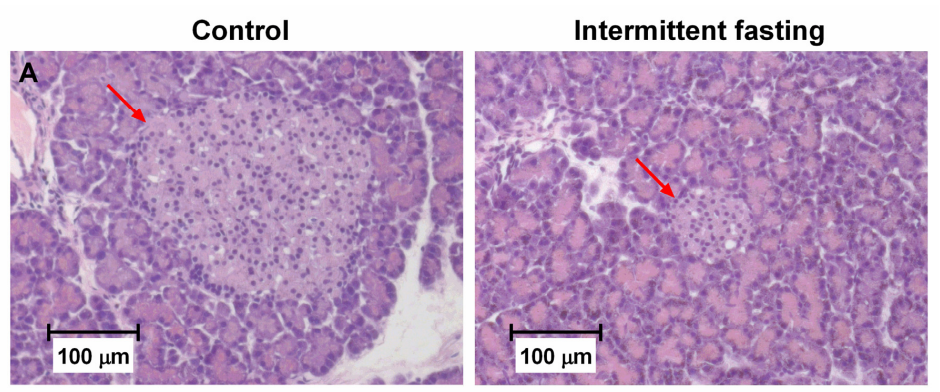

B

C
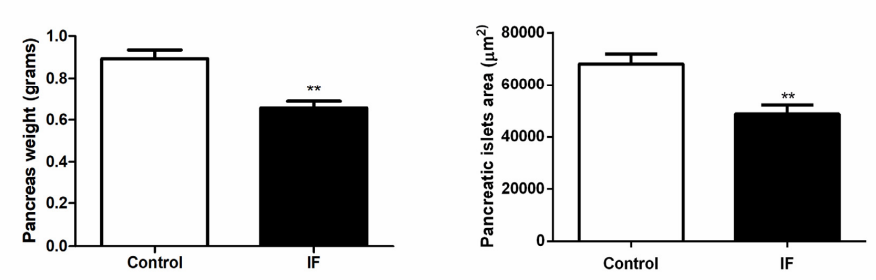

Figure 11. (A) Pancreatic islet of the longitudinal cut of pancreas caudal portion, (B) pancreas weight related to body weight, and (C) pancreatic islets area from Wistar rats submitted to IF for 12 weeks (Hematoxylin-eosin stained tissue (H\&E) and 100x magnification). The results were presented as the mean \pm standard error of the mean (SEM) with 5 different animals for each group. ${ }^{* *} p<0.005$ compared to the control, as indicated by Student's $t$-test. 
The viability of the dispersed cells from pancreatic islets was assessed and no significant difference in the number of viable cells (Figure 12A) and number of dead cells was observed (Figure 12C). However, we observed a significant increase of $27.8 \%$ in the number of apoptotic cells (Figure 11B).
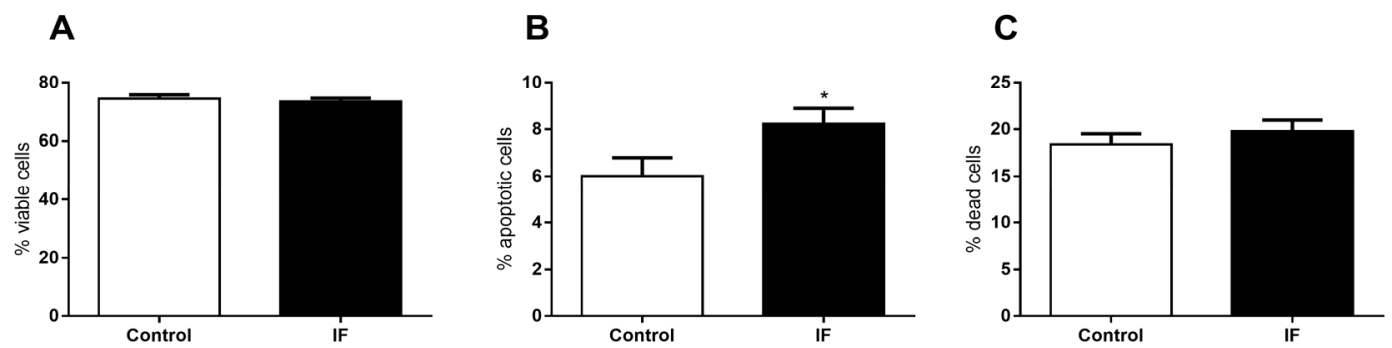

Figure 12. (A) Viability, (B) the percentage of apoptotic cells, and (C) the percentage of dead cells of dispersed cells from pancreatic islet isolated from Wistar rats submitted to IF for 12 weeks. The results are presented as the mean \pm standard error of the mean (SEM) with 5 different cellular preparations for each group. ${ }^{*} p<0.05$ compared to the control, as indicated by Student's $t$-test.

\subsection{ROS Production of Dispersed Cells from Pancreatic Islets}

We observed an $80.2 \%$ increase in the net fluorescence induced by reactive oxygen species (ROS) in the presence of glucose $2.8 \mathrm{mM}$ after incubation with the redox-sensitive probe DHE (Dihydroethidium). No significant difference was found between the groups at $16.7 \mathrm{mM}$ glucose level (Figure 13A).
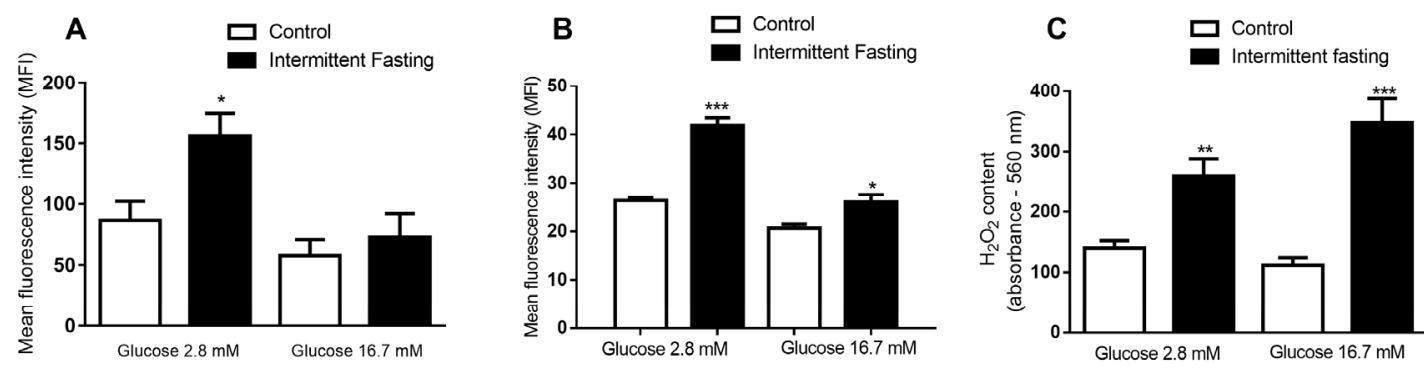

Figure 13. (A) Mean fluorescence intensity (MFI) emitted by a dihydroethidium (DHE) probe, (B) MFI emitted by a MitoSox Red probe, and (C) the absorbance emitted by the Amplex Red probe of dispersed cells from a pancreatic islet isolated from Wistar rats submitted to IF for 12 weeks after one hour of incubation in the presence of 2.8 and $16.7 \mathrm{mM}$ glucose. The results are presented as the means \pm standard error of the mean (EPM) with 6 different cellular preparations for each group. ${ }^{*} p<0.05$, ${ }^{* *} p<0.005$, and ${ }^{* * *} p<0.0005$, compared to the respective control, as indicated by Student's t-test.

Net mitochondrial ROS production was also measured in the presence of 2.8 and $16.7 \mathrm{mM}$ glucose after incubation with the MitoSox Red probe (Figure 13B). After 12 weeks of intermittent fasting, a significant increase in fluorescence associated to ROS production was revealed $(59.2 \%$ in low glucose and $26 \%$ in high glucose concentration).

Finally, we measured the concentrations of hydrogen peroxide $\left(\mathrm{H}_{2} \mathrm{O}_{2}\right)$ in the presence of 2.8 and $16.7 \mathrm{mM}$ of glucose after incubation with the Amplex Red probe (Figure 13C). IF caused a significant increase in $\mathrm{H}_{2} \mathrm{O}_{2}$ detection in the presence of both glucose concentrations compared to the values of the control group. At low glucose levels, an increment of $85 \%$ was observed, while, at at $16.7 \mathrm{mM}$ glucose, an increase of $211 \%$ was measured.

\subsection{Antioxidant Systems}

Lastly, we analyzed two antioxidant enzyme expressions: mitochondrial superoxide dismutase (SOD2), also known as manganese-dependent superoxide dismutase (MnSOD), and glutathione 
peroxidase 1 (GPX1). The enzymes were measured by electrophoresis gel and calculated in relation to $\alpha$-tubulin protein expression. Intermittent fasting resulted in a significant increase (by $70.86 \%$ ) in SOD2 expression (Figure 14A). However, after intermittent fasting, GPX1 expression was not different from the values found in the control group.
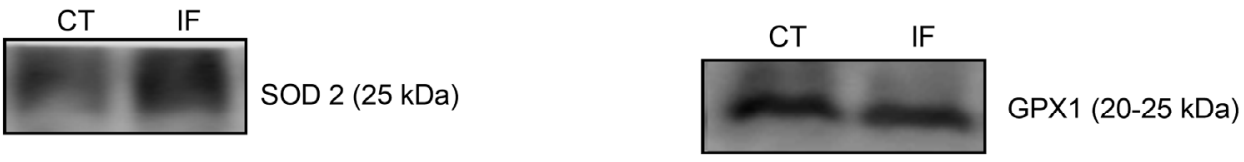

A
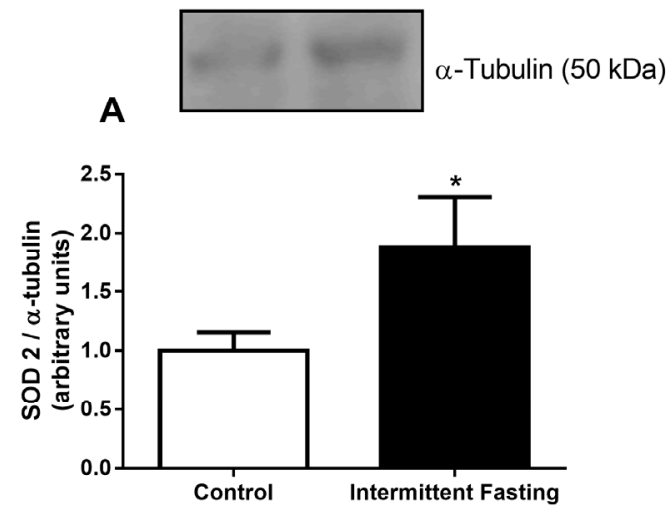

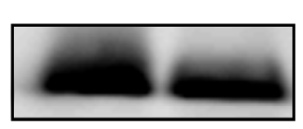

$\alpha$-tubulin $(50 \mathrm{kDa})$

Figure 14. (A) Superoxide dismutase 2 (SOD2) and (B) glutathione peroxidase 1 (GPX1) expression of pancreatic islets isolated from Wistar rats submitted to IF for 12 weeks. The results are presented as the means \pm standard error of the mean (SEM) with 5 different cellular preparations for each group. ${ }^{*} p<0.05$ compared to the control, as indicated by Student's $t$-test.

\section{Discussion}

Alternate-day intermittent fasting (IF) is a relatively new dietary approach that has been promoted to help weight management. As a result, the number of people adhering to this new diet grows every day. We are aware that children are not usually placed on IF diets. However, our society is constantly changing, and with increasing levels of obesity and overweight in children, it is possible that this may be a dietary approach recommended by nutrition professionals in the future. Hence, we need to study possible consequences of this practice in young organisms, as the adverse effects of alternate-day IF have not been fully elucidated.

Compared with daily calorie restriction, intermittent fasting in obese volunteers did not produce better adherence, weight loss, weight maintenance, or improvement in risk indicators for cardiovascular disease. Rather, the dropout rate and hunger in the IF fasting group was higher than that in the daily calorie restriction group, and the authors concluded that IF may be less sustainable in the long-term for obese individuals [56,57].

In this study, long-term IF was successful in reducing body weight gain (Figure 2A) in female Wistar rats, and this may be due to lower average food intake (by 35\%) (Figure 3A). Weight loss as a consequence of IF has been reported in previous studies in both animal $[58,59]$ and human subjects [60-62]. However, Sakamoto and Grunewald showed that IF in 4-week-old rats markedly reduced the growth rate and the animals had smaller livers, kidneys, hearts, tibias and tibialis anterior muscles [63]. In this study, the treatment was also initiated in young animals (4-weeks old) and, as can be seen in Figure 2B (reduced naso-anal length) and 2C (reduced tibial length), may affect growth since the animal is developing [64].

As previously reported, IF in slim and healthy people for 2 weeks [65] or 1 month [66] showed a significant decrease in resting energy expenditure. Hence, the animals could gain weight in relation to control animals if the food intake in both groups were the same, assuming that IF promotes lower energy expenditure. Additionally, a hyperphagic behavior on free feeding days (Figure 3A) was observed, which caused a large increase in stomach dimensions (3B-D). There are records of IF-induced increased 
expression of the agouti-related peptide (AGRP), neuropeptide Y (NPY) and orexin due to intermittent fasting in rodents, even when the stomach was full $[58,67,68]$. These orexigenic neurotransmitters are involved in appetite modulation and metabolic regulation [69], and their increasing concentrations in plasma could explain the increase in food intake. There are also several human studies showing increased subjective appetite sensation as a result of fasting cycles [70-72].

It has been previously reported that IF promotes a greater deposition of triacylglycerides in the white adipose tissue by increasing the expression of genes involved in lipid storage, such as fatty-specific protein 27 (FSP27) [73]. In 1928, Lee described a rapid method to quantify obesity from body weight and naso-anal length values. The result defines the nutritional status, called the Lee index, which correlates positively with adipose tissue mass. [74,75]. In this study, the values obtained from this index reveal a slight, but significant, increase in the IF group values compared to the control group (Figure 2D), which does not mean that the IF animals are obese, but corroborates the largest adipose reserve found (Figure $4 \mathrm{~A}-\mathrm{D}$ ).

No significant differences were found between groups neither in blood glucose concentrations after oral glucose administration (Figure 6A) nor in $\mathrm{HbA} 1 \mathrm{c}$ (Figure 6C). These results contradict previously published studies, which show a reduction in blood glucose concentrations. [25,76,77]. Nevertheless, in this case, the lower glycaemia can be a consequence of large amounts of circulating insulin concentrations (Figure 8) since insulin is the hypoglycemic hormone that allows glucose to enter in insulin-sensitive target cells. The decrease in liver weight observed may be related to lower glycogen reserves (Figure 5). The significant drop in hepatic glycogen and muscle glycogen concentrations (Supplemental Figure S2) may result in increased fatigue and impaired maintenance of normoglycemia between feeding periods [78].

Our data show changes in body composition with decreased muscle mass (Figure 4E-G) and increased fat mass (Figure 4B-D), in contrast to the literature data, which generally show reduced body fat and maintenance of lean mass. [28,62,79-81]. However, a decrease in lean mass after only 1 month of IF has been reported in adolescent girls [42]. An increase in body mass index was found with IF only in women, with a reduction in this parameter in men [82]. Another study found that improvements in body composition are less pronounced in younger women [62]. In female mice, IF did not cause weight loss [83]. It is possible that intermittent fasting causes more adverse effects on the body composition of females, and this could be accentuated in younger and developing organisms.

Glucose and insulin plasma concentrations under fasting conditions in both healthy and type 2 diabetes mellitus (T2DM) subjects are expressed at characteristic concentrations for each individual's nutritional status. Basal insulin concentrations are a consequence of fasting glucose concentrations, the secretory capacity of pancreatic $\beta$-cells, and the rate of pulsatile insulin secretion. Previous work shows that IF increases both basal and glucose-stimulated insulin secretion in mice with diet-induced obesity [83]. This increase in insulin concentrations (Figure 8A), also found in in vitro pancreatic islets (Figure 8B-D), suggests resistance to this hormone, as evidenced by a significant increase in the homeostasis model assessment (HOMA) index (Figure 9), and impaired AKT phosphorylation in muscle, liver, and adipose tissue (Figure 10).

HOMA is a mathematical calculation based on fasting insulinemia and glycaemia, proposed by David Matheus [53] as a simple and fast way to determine insulin resistance (HOMA-IR) and the functional capacity of pancreatic $\beta$-cells (HOMA-BETA). Similar data were found in a study performed with male rats submitted to 5 weeks of IF and likewise in volunteers during 1 month of fasting, both showing increased plasma insulin and HOMA indexes [38,84].

One hypothesis for this insulin resistance induced by fasting is increased secretion of ghrelin. The secretion of this gastric hormone is elevated in calorie restricted mice, rats, and humans [85]. Ghrelin is produced and secreted predominantly in the oxyntic mucosa of stomach (approximately $60-70 \%$ of circulating ghrelin), and low plasma ghrelin concentrations are associated with elevated fasting insulin concentrations and insulin resistance, suggesting both physiological and pathophysiological roles in glucose metabolism $[86,87]$. Barazzoni et al. observed that, in rats, sustained ghrelin administration 
reduced hepatic AKT phosphorylation. The deregulation of AKT phosphorylation has been suggested to occur under insulin resistance conditions and diabetes [88].

Although insulin tolerance tests showed no differences in glycaemia values at any time studied (Figure 7A), nor in glucose decay constant values (Figure 7C), impaired AKT phosphorylation in muscle, liver, and WAT indicates impaired insulin action (Figure 10). Intermittent fasting for 8 months in rats caused impaired glucose clearance, as reported by Cerqueira et al. [89]. In addition, intermittent food restriction in female rats for 6 weeks induced glucose intolerance and detrimental hypothalamic alterations coupled with compulsive eating behavior [90]. Thus, frequent feeding and fasting cycles may be harmful and associated with insulin resistance, increasing risks of T2DM. A hyperinsulinemic-euglycemic clamp was not conducted in this work and should be included in future studies.

There are several studies that suggest that high insulin concentrations are associated with typical pathologies of the metabolic syndrome, such as insulin resistance [91-97], obesity [98-103], hypertension, cardiovascular diseases [104-108], atherosclerosis [109], and hepatic steatosis [110,111]. In general, the development of T2DM begins when the metabolic demand for insulin is greater, due to peripheral insulin resistance. This insulin resistance generally precedes the development of hyperglycaemia. In other words, there is a period of normoglycaemia, where pancreatic $\beta$-cells compensate insulin resistance by increasing insulin secretion [112-115]. However, this compensatory hyperinsulinemia can cause damage to the secretory cell in the long run, leading to $\beta$-cell apoptosis and the development of T2DM [116-118].

Corroborating with this idea, the decreased pancreas weight and pancreatic islet area (Figure 11), as well as increased apoptotic cells in pancreatic islets (Figure 12), reinforce the hypothesis that IF may be detrimental to the endocrine pancreas and represents an unhealthy long-term diet. Although we must be cautious when comparing the effects to humans, this study in an animal model is an important tool to evaluate the potential impacts of this diet in a standardized manner, with minimal artifact interference. Moreover, animal studies allow us to evaluate the effects directly in important organs, such as the pancreas, given that data in humans is obviously sparse or non-existent as to whether long-term intermittent fasting diets affect pancreatic islets.

Lastly, 8 weeks of IF caused no difference in net ROS production between groups at any of the glucose concentrations studied (Supplemental Figure S3). However, 12 weeks of IF increased total (Figure 13A) and mitochondrial (Figure 13B) net ROS production in the pancreas, besides increasing hydrogen peroxide levels (Figure 13C), together showing that the effects are accentuated by a longer time of treatment and lead to oxidative imbalance, as previously shown by Cerqueira et al. [89] in other tissues. Intermittent fasting in mice showed that, on ad libitum feeding days, when the animal ingests a large amount of food, ROS production is enhanced due to increased mitochondrial respiration [21].

These ROS increments caused the enhancement antioxidant defenses, as evidenced by increased SOD2 (Figure 14A), that catalyzes the dismutation of superoxide into $\mathrm{O}_{2}$ and $\mathrm{H}_{2} \mathrm{O}_{2}$, which are less damaging molecules. This cellular response promoted by 12 weeks of IF diet may be important to mitigate oxidative stress, since increased ROS production has been reported to cause a loss of function and even apoptosis in several cell types [119-126], including pancreatic islets [127-133].

The insulin receptor is essential for pancreatic $\beta$-cell function and survival. The insulin signaling networks contain many proteins that are established regulators of apoptosis and proliferation. Insulin directly prevents apoptosis in human and mouse islets, as well as in $\beta$-cell lines $[134,135]$. Cerqueira et al. showed that long-term intermittent feeding leads to redox imbalance and peripheral insulin receptor nitration [89]. Thus, increased oxidative stress induced by 12 weeks IF may be accompanied by the oxidation of the insulin receptor in pancreatic $\beta$-cells and the impairment of cell survival. However, a more detailed study of oxidative stress induced by fasting on the protective effects of autocrine insulin signaling is needed.

Several studies show that the effects of IF depend on several factors, such as the period of day in which fasting is practiced. Time restricted feeding (TRF) is a type of IF that involves eating all 
nutrients within a few hours every day, usually up to 12 hours. Studies suggest that, depending on the time of the eating window, TRF leads to opposite effects. Restricting food intake to the resting phase worsened fasting and postprandial glucose concentrations, blood pressure, and lipid concentrations in humans [32,136], and induced leptin resistance that contributes to the development of obesity and metabolic disorders in mice [137]. However, restricting food intake to the active phase improved insulin sensitivity, blood pressure, glucose tolerance, and oxidative stress [8,138,139].

Corroborating these results, there are several long-term studies in humans showing detrimental effects of skipping breakfast, which is a type of IF by prolonging overnight fasting to the active phase. Breakfast skipping is associated with a significantly increased risk of overweight and obesity, poorer glycemic control, insulin resistance, and an increased risk of T2DM [140-145]. Considering that the present study evaluated juvenile rats and that they present a different endocrinology response to adults, our results only apply to juveniles. In developing organisms, growth hormone may play an important role in inducing insulin resistance under fasting stress conditions, which may be significant for the defense against hypoglycemia [146]. Besides, further long-term research is necessary to investigate which IF protocol is more suitable to reduce these side effects and improve health, before IF can be considered a good alternative for weight management in young individuals.

\section{Conclusions}

Intermittent fasting is effective for weight loss, but the long-term safety has been questioned. Considering increasing levels of obesity and overweight in children, we studied possible consequences of this practice in young animals. We have shown here that 12 weeks of alternate-day intermittent fasting in young female Wistar rats causes several changes that can be detrimental in the long run to young individuals, including the elevation of pancreatic islet cells apoptosis and ROS production. We also found a reduction in pancreatic islet mass, a large increase in insulin secretion, and signs of insulin resistance by reduced AKT phosphorylation in muscle and adipose tissue, which may be a risk factor for T2DM. Besides that, we noticed a remodeling of body composition, with increased body fat and decreased muscle mass. Taken together, these findings suggest that caution may be warranted when unrestrictedly recommending intermittent fasting to young individuals, especially for people with compromised glucose metabolism. This study was conducted in healthy juvenile rats and these findings may not translate into adult humans. Further studies are required.

Supplementary Materials: The following are available online at http://www.mdpi.com/2072-6643/12/4/1029/s1. Figure S1 Macro-nutrients of the standard rodent chow (Nuvilab, Sao Paulo, SP, Brazil), Figure S2 Gastrocnemius glycogen content, Figure S3 Mean fluorescence intensity (MFI) emitted by dihydroethidium (DHE) probe of dispersed cells from pancreatic islet isolated from Wistar rats submitted to IF for 8 weeks after one hour of incubation in the presence of 2.8 and $16.7 \mathrm{mM}$ glucose.

Author Contributions: Conceptualization, A.C.M., P.R.; methodology, A.C.M.; formal analysis, A.C.M.; investigation, A.C.M., E.A.V.-B., A.C.P.-C., J.S.M.L., C.F.L., P.R.; data curation, A.C.M., E.A.V.-B., A.R.C., A.C.P.-C., C.F.L.; writing-original draft preparation, A.C.M.; writing-review and editing, A.C.M. and H.E.; visualization, H.E.; supervision, A.R.C.; project administration, A.C.M.; funding acquisition, A.C.M. and A.R.C. All authors have read and agreed to the published version of the manuscript.

Funding: This research was funded by National Council for Scientific and Technological Development (CNPq), grant number 166017/2014-0.

Acknowledgments: The authors would like to thank Marlene Santos da Rocha for the excellent technical assistance, Alicia Juliana Kowaltowski for revising the English writing, and Altay Alves Lino de Souza for revising statistical analyses.

Conflicts of Interest: The authors declare that there is no conflict of interest. 


\section{References}

1. Tuomilehto, J.; Lindström, J.; Eriksson, J.G.; Valle, T.T.; Hämäläinen, H.; Ilanne-Parikka, P.; Keinänen-Kiukaanniemi, S.; Laakso, M.; Louheranta, A.; Rastas, M.; et al. Prevention of type 2 diabetes mellitus by changes in lifestyle among subjects with impaired glucose tolerance. N. Engl. J. Med. 2001, 344, 1343-1350. [CrossRef]

2. Thent, Z.C.; Das, S.; Henry, L.J. Role of exercise in the management of diabetes mellitus: the global scenario. PLoS ONE 2013, 8, e80436. [CrossRef]

3. Pilon, B. Eat Stop Eat; Medwin House Inc.: Ontario, Canada, 2007.

4. Mosley, M.; Spencer, M. A Dieta dos 2 Dias-The Fast Diet; Sextante: Belo Horizonte, Brazil, 2013.

5. Harris, L.; Hamilton, S.; Azevedo, L.B.; Olajide, J.; De Brún, C.; Waller, G.; Whittaker, V.; Sharp, T.; Lean, M.; Hankey, C.; et al. Intermittent fasting interventions for treatment of overweight and obesity in adults: A systematic review and meta-analysis. JBI Database Syst. Rev. Implement. Rep. 2018, 16, 507-547. [CrossRef] [PubMed]

6. Harvie, M.; Wright, C.; Pegington, M.; McMullan, D.; Mitchell, E.; Martin, B.; Cutler, R.G.; Evans, G.; Whiteside, S.; Maudsley, S.; et al. The effect of intermittent energy and carbohydrate restriction v. daily energy restriction on weight loss and metabolic disease risk markers in overweight women. Br. J. Nutr. 2013, 110, 1534-1547. [CrossRef] [PubMed]

7. Gabel, K.; Hoddy, K.K.; Haggerty, N.; Song, J.; Kroeger, C.M.; Trepanowski, J.F.; Panda, S.; Varady, K.A. Effects of 8-hour time restricted feeding on body weight and metabolic disease risk factors in obese adults: A pilot study. Nutr. Healthy Aging 2018, 4, 345-353. [CrossRef] [PubMed]

8. Sutton, E.F.; Beyl, R.; Early, K.S.; Cefalu, W.T.; Ravussin, E.; Peterson, C.M. Early Time-Restricted Feeding Improves Insulin Sensitivity, Blood Pressure, and Oxidative Stress Even without Weight Loss in Men with Prediabetes. Cell Metab. 2018, 27, 1212-1221.E3. [CrossRef] [PubMed]

9. Harvie, M.N.; Pegington, M.; Mattson, M.P.; Frystyk, J.; Dillon, B.; Evans, G.; Cuzick, J.; Jebb, S.A.; Martin, B.; Cutler, R.G.; et al. The effects of intermittent or continuous energy restriction on weight loss and metabolic disease risk markers: A randomized trial in young overweight women. Int. J. Obes. 2011, 35, 714-727. [CrossRef] [PubMed]

10. Corley, B.T.; Carroll, R.W.; Hall, R.M.; Weatherall, M.; Parry-Strong, A.; Krebs, J.D. Intermittent fasting in Type 2 diabetes mellitus and the risk of hypoglycaemia: A randomized controlled trial. Diabet. Med. 2018. [CrossRef]

11. Marosi, K.; Moehl, K.; Navas-Enamorado, I.; Mitchell, S.J.; Zhang, Y.; Lehrmann, E.; Aon, M.A.; Cortassa, S.; Becker, K.G.; Mattson, M.P. Metabolic and molecular framework for the enhancement of endurance by intermittent food deprivation. FASEB J. 2018. [CrossRef]

12. Almeneessier, A.S.; Alzoghaibi, M.; BaHammam, A.A.; Ibrahim, M.G.; Olaish, A.H.; Nashwan, S.Z.; BaHammam, A.S. The effects of diurnal intermittent fasting on the wake-promoting neurotransmitter orexin-A. Ann. Thorac. Med. 2018, 13, 48-54. [CrossRef]

13. Goodrick, C.L.; Ingram, D.K.; Reynolds, M.A.; Freeman, J.R.; Cider, N. Effects of intermittent feeding upon body weight and lifespan in inbred mice: Interaction of genotype and age. Mech. Ageing Dev. 1990, 55, 69-87. [CrossRef]

14. Heilbronn, L.K.; Smith, S.R.; Martin, C.K.; Anton, S.D.; Ravussin, E. Alternate-day fasting in nonobese subjects: Effects on body weight, body composition, and energy metabolism. Am. J. Clin. Nutr. 2005, 81, 69-73. [CrossRef] [PubMed]

15. Johnson, J.B.; Laub, D.R.; John, S. The effect on health of alternate day calorie restriction: eating less and more than needed on alternate days prolongs life. Med. Hypotheses 2006, 67, 209-211. [CrossRef] [PubMed]

16. Caviezel, F.; Margonato, A.; Slaviero, G.; Bonetti, F.; Vicedomini, G.; Cattaneo, A.G.; Pozza, G. Early improvement of left ventricular function during caloric restriction in obesity. Int. J. Obes. 1986, 10, 421-426. [PubMed]

17. Bruce-Keller, A.J.; Umberger, G.; McFall, R.; Mattson, M.P. Food restriction reduces brain damage and improves behavioral outcome following excitotoxic and metabolic insults. Ann. Neurol. 1999, 45, 8-15. [CrossRef]

18. Duan, W.; Guo, Z.; Mattson, M.P. Brain-derived neurotrophic factor mediates an excitoprotective effect of dietary restriction in mice. J. Neurochem. 2001, 76, 619-626. [CrossRef] 
19. Kim, J.; Kang, S.W.; Mallilankaraman, K.; Baik, S.H.; Lim, J.C.; Balaganapathy, P.; She, D.T.; Lok, K.Z.; Fann, D.Y.; Thambiayah, U.; et al. Transcriptome Analysis Reveals Intermittent Fasting-Induced Genetic Changes in Ischemic Stroke. Hum. Mol. Genet. 2018. [CrossRef]

20. Wan, R.; Camandola, S.; Mattson, M.P. Intermittent fasting and dietary supplementation with 2-deoxy-D-glucose improve functional and metabolic cardiovascular risk factors in rats. FASEB J. 2003, 17, 1133-1134. [CrossRef]

21. Anson, R.M.; Guo, Z.; de Cabo, R.; Iyun, T.; Rios, M.; Hagepanos, A.; Ingram, D.K.; Lane, M.A.; Mattson, M.P. Intermittent fasting dissociates beneficial effects of dietary restriction on glucose metabolism and neuronal resistance to injury from calorie intake. Proc. Natl. Acad. Sci. USA 2003, 100, 6216-6220. [CrossRef]

22. Bouguerra, R.; Jabrane, J.; Maâtki, C.; Ben Salem, L.; Hamzaoui, J.; El Kadhi, A.; Ben Rayana, C.; Ben Slama, C. Ramadan fasting in type 2 diabetes mellitus. Ann. Endocrinol. (Paris) 2006, 67, 54-59. [CrossRef]

23. Khaled, B.M.; Bendahmane, M.; Belbraouet, S. Ramadan fasting induces modifications of certain serum components in obese women with type 2 diabetes. Saudi Med. J. 2006, 27, 23-26. [PubMed]

24. Shariatpanahi, Z.V.; Shariatpanahi, M.V.; Shahbazi, S.; Hossaini, A.; Abadi, A. Effect of Ramadan fasting on some indices of insulin resistance and components of the metabolic syndrome in healthy male adults. $\mathrm{Br}$. J. Nutr. 2008, 100, 147-151. [CrossRef] [PubMed]

25. Belkacemi, L.; Selselet-Attou, G.; Bulur, N.; Louchami, K.; Sener, A.; Malaisse, W.J. Intermittent fasting modulation of the diabetic syndrome in sand rats. III. Post-mortem investigations. Int. J. Mol. Med. 2011, 27, 95-102. [CrossRef] [PubMed]

26. Teng, N.I.; Shahar, S.; Rajab, N.F.; Manaf, Z.A.; Johari, M.H.; Ngah, W.Z. Improvement of metabolic parameters in healthy older adult men following a fasting calorie restriction intervention. Aging Male 2013, 16, 177-183. [CrossRef] [PubMed]

27. Gnanou, J.V.; Caszo, B.A.; Khalil, K.M.; Abdullah, S.L.; Knight, V.F.; Bidin, M.Z. Effects of Ramadan fasting on glucose homeostasis and adiponectin levels in healthy adult males. J. Diabetes Metab. Disord. 2015, 14, 55. [CrossRef] [PubMed]

28. Tinsley, G.M.; La Bounty, P.M. Effects of intermittent fasting on body composition and clinical health markers in humans. Nutr. Rev. 2015, 73, 661-674. [CrossRef] [PubMed]

29. Castrogiovanni, P.; Li Volti, G.; Sanfilippo, C.; Tibullo, D.; Galvano, F.; Vecchio, M.; Avola, R.; Barbagallo, I.; Malaguarnera, L.; Castorina, S.; et al. Fasting and Fast Food Diet Play an Opposite Role in Mice Brain Aging. Mol. Neurobiol. 2018. [CrossRef]

30. Hu, Y.; Zhang, M.; Chen, Y.; Yang, Y.; Zhang, J.J. Postoperative intermittent fasting prevents hippocampal oxidative stress and memory deficits in a rat model of chronic cerebral hypoperfusion. Eur. J. Nutr. 2018. [CrossRef]

31. Chentli, F.; Azzoug, S.; Amani, M.1.A.; Elgradechi, A. Diabetes mellitus and Ramadan in Algeria. Indian J. Endocrinol. Metab. 2013, 17, S295-S298. [CrossRef]

32. Stote, K.S.; Baer, D.J.; Spears, K.; Paul, D.R.; Harris, G.K.; Rumpler, W.V.; Strycula, P.; Najjar, S.S.; Ferrucci, L.; Ingram, D.K.; et al. A controlled trial of reduced meal frequency without caloric restriction in healthy, normal-weight, middle-aged adults. Am. J. Clin. Nutr. 2007, 85, 981-988. [CrossRef]

33. al-Hadramy, M.S.; Zawawi, T.H.; Abdelwahab, S.M. Altered cortisol levels in relation to Ramadan. Eur. J. Clin. Nutr. 1988, 42, 359-362. [PubMed]

34. Bogdan, A.; Bouchareb, B.; Touitou, Y. Ramadan fasting alters endocrine and neuroendocrine circadian patterns. Meal-time as a synchronizer in humans? Life Sci. 2001, 68, 1607-1615. [CrossRef]

35. Ben Salem, L.; Bchir, S.; Bouguerra, R.; Ben Slama, C. Cortisol rhythm during the month of Ramadan. East Mediterr. Health J. 2003, 9, 1093-1098. [PubMed]

36. Roky, R.; Houti, I.; Moussamih, S.; Qotbi, S.; Aadil, N. Physiological and chronobiological changes during Ramadan intermittent fasting. Ann. Nutr. Metab. 2004, 48, 296-303. [CrossRef]

37. Haouari, M.; Haouari-Oukerro, F.; Sfaxi, A.; Ben Rayana, M.C.; Kâabachi, N.; Mbazâa, A. How Ramadan fasting affects caloric consumption, body weight, and circadian evolution of cortisol serum levels in young, healthy male volunteers. Horm. Metab. Res. 2008, 40, 575-577. [CrossRef]

38. Bahijri, S.; Borai, A.; Ajabnoor, G.; Abdul Khaliq, A.; AlQassas, I.; Al-Shehri, D.; Chrousos, G. Relative metabolic stability, but disrupted circadian cortisol secretion during the fasting month of Ramadan. PLoS ONE 2013, 8, e60917. [CrossRef] 
39. Guerrero-Morilla, R.; Ramírez-Rodrigo, J.; Ruiz-Villaverde, G.; Sánchez-Caravaca, M.A.; Pérez-Moreno, B.A.; Villaverde-Gutiérrez, C. Endocrine-metabolic adjustments during Ramadan fasting in young athletes. Arch. Latinoam. Nutr. 2013, 63, 14-20.

40. Ajabnoor, G.M.; Bahijri, S.; Borai, A.; Abdulkhaliq, A.A.; Al-Aama, J.Y.; Chrousos, G.P. Health impact of fasting in Saudi Arabia during Ramadan: association with disturbed circadian rhythm and metabolic and sleeping patterns. PLoS ONE 2014, 9, e96500. [CrossRef]

41. Heilbronn, L.K.; Civitarese, A.E.; Bogacka, I.; Smith, S.R.; Hulver, M.; Ravussin, E. Glucose tolerance and skeletal muscle gene expression in response to alternate day fasting. Obes. Res. 2005, 13, 574-581. [CrossRef]

42. Reiches, M.W.; Moore, S.E.; Prentice, A.M.; Ellison, P.T. Endocrine responses, weight change, and energy sparing mechanisms during Ramadan among Gambian adolescent women. Am. J. Hum. Biol. 2014, 26, 395-400. [CrossRef]

43. Munsters, M.J.; Saris, W.H. Effects of meal frequency on metabolic profiles and substrate partitioning in lean healthy males. PLoS ONE 2012, 7, e38632. [CrossRef] [PubMed]

44. Bosboom, R.S.; Zweens, J.; Bouman, P.R. Effects of feeding and fasting on the insulin secretory response to glucose and sulfonylureas in intact rats and isolated perfused rat pancreas. Diabetologia 1973, 9, 243-250. [CrossRef] [PubMed]

45. Svenningsen, A.; Bonnevie-Nielsen, V. Effects of fasting on beta-cell function, body fat, islet volume, and total pancreatic insulin content. Metabolism 1984, 33, 612-616. [CrossRef]

46. Gasa, R.; Sener, A.; Malaisse, W.J.; Gomis, R. Apparent starvation-induced repression of pancreatic islet glucokinase. Biochem. Mol. Med. 1995, 56, 99-103. [CrossRef]

47. Bone, A.J.; Howell, S.L. Alterations in regulation of insulin biosynthesis in pregnancy and starvation studied in isolated rat islets of langerhans. Biochem. J. 1977, 166, 501-507. [CrossRef]

48. Hedeskov, C.J.; Capito, K. The effect of starvation on insulin secretion and glucose metabolism in mouse pancreatic islets. Biochem. J. 1974, 140, 423-433. [CrossRef]

49. Tadayyon, M.; Bonney, R.C.; Green, I.C. Starvation decreases insulin secretion, prostaglandin E2 production and phospholipase A2 activity in rat pancreatic islets. J. Endocrinol. 1990, 124, 455-461. [CrossRef]

50. Hedeskov, C.J.; Capito, K. The pentose cycle and insulin release in isolated mouse pancreatic islets during starvation. Biochem. J. 1975, 152, 571-576. [CrossRef]

51. Munhoz, A.C.; Riva, P.; Simões, D.; Curi, R.; Carpinelli, A.R. Control of Insulin Secretion by Production of Reactive Oxygen Species: Study Performed in Pancreatic Islets from Fed and 48-Hour Fasted Wistar Rats. PLoS ONE 2016, 11, e0158166. [CrossRef]

52. Bernardis, L.L.; Patterson, B.D. Correlation between "Lee index" and carcass fat content in weanling and adult female rats with hypothalamic lesions. J. Endocrinol. 1968, 40, 527-528. [CrossRef]

53. Matthews, D.R.; Hosker, J.P.; Rudenski, A.S.; Naylor, B.A.; Treacher, D.F.; Turner, R.C. Homeostasis model assessment: Insulin resistance and beta-cell function from fasting plasma glucose and insulin concentrations in man. Diabetologia 1985, 28, 412-419. [CrossRef] [PubMed]

54. Lacy, P.E.; Kostianovsky, M. Method for the isolation of intact islets of Langerhans from the rat pancreas. Diabetes 1967, 16, 35-39. [CrossRef] [PubMed]

55. Scott, A.M.; Atwater, I.; Rojas, E. A method for the simultaneous measurement of insulin release and B cell membrane potential in single mouse islets of Langerhans. Diabetologia 1981, 21, 470-475. [CrossRef] [PubMed]

56. Trepanowski, J.F.; Kroeger, C.M.; Barnosky, A.; Klempel, M.C.; Bhutani, S.; Hoddy, K.K.; Gabel, K.; Freels, S.; Rigdon, J.; Rood, J.; et al. Effect of Alternate-Day Fasting on Weight Loss, Weight Maintenance, and Cardioprotection Among Metabolically Healthy Obese Adults: A Randomized Clinical Trial. JAMA Intern. Med. 2017, 177, 930-938. [CrossRef]

57. Sundfør, T.M.; Svendsen, M.; Tonstad, S. Effect of intermittent versus continuous energy restriction on weight loss, maintenance and cardiometabolic risk: A randomized 1-year trial. Nutr. Metab. Cardiovasc. Dis. 2018, 28, 698-706. [CrossRef]

58. Chausse, B.; Solon, C.; Caldeira da Silva, C.C.; Masselli Dos Reis, I.G.; Manchado-Gobatto, F.B.; Gobatto, C.A.; Velloso, L.A.; Kowaltowski, A.J. Intermittent fasting induces hypothalamic modifications resulting in low feeding efficiency, low body mass and overeating. Endocrinology 2014, 155, 2456-2466. [CrossRef]

59. Chausse, B.; Vieira-Lara, M.A.; Sanchez, A.B.; Medeiros, M.H.; Kowaltowski, A.J. Intermittent fasting results in tissue-specific changes in bioenergetics and redox state. PLoS ONE 2015, 10, e0120413. [CrossRef] 
60. Varady, K.A.; Bhutani, S.; Klempel, M.C.; Kroeger, C.M.; Trepanowski, J.F.; Haus, J.M.; Hoddy, K.K.; Calvo, Y. Alternate day fasting for weight loss in normal weight and overweight subjects: A randomized controlled trial. Nutr. J. 2013, 12, 146. [CrossRef]

61. Coutinho, S.R.; Halset, E.H.; Gåsbakk, S.; Rehfeld, J.F.; Kulseng, B.; Truby, H.; Martins, C. Compensatory mechanisms activated with intermittent energy restriction: A randomized control trial. Clin. Nutr. 2017. [CrossRef]

62. López-Bueno, M.; González-Jiménez, E.; Navarro-Prado, S.; Montero-Alonso, M.A.; Schmidt-RioValle, J. Influence of age and religious fasting on the body composition of Muslim women living in a westernized context. Nutr. Hosp. 2014, 31, 1067-1073. [CrossRef]

63. Sakamoto, K.; Grunewald, K.K. Beneficial effects of exercise on growth of rats during intermittent fasting. J. Nutr. 1987, 117, 390-395. [CrossRef] [PubMed]

64. Sengupta, P. The Laboratory Rat: Relating Its Age with Human's. Int. J. Prev. Med. 2013, 4, $624-630$. [PubMed]

65. Soeters, M.R.; Lammers, N.M.; Dubbelhuis, P.F.; Ackermans, M.; Jonkers-Schuitema, C.F.; Fliers, E.; Sauerwein, H.P.; Aerts, J.M.; Serlie, M.J. Intermittent fasting does not affect whole-body glucose, lipid, or protein metabolism. Am. J. Clin. Nutr. 2009, 90, 1244-1251. [CrossRef] [PubMed]

66. el Ati, J.; Beji, C.; Danguir, J. Increased fat oxidation during Ramadan fasting in healthy women: An adaptative mechanism for body-weight maintenance. Am. J. Clin. Nutr. 1995, 62, 302-307. [CrossRef] [PubMed]

67. Gotthardt, J.D.; Verpeut, J.L.; Yeomans, B.L.; Yang, J.A.; Yasrebi, A.; Roepke, T.A.; Bello, N.T. Intermittent Fasting Promotes Fat Loss with Lean Mass Retention, Increased Hypothalamic Norepinephrine Content, and Increased Neuropeptide Y Gene Expression in Diet-Induced Obese Male Mice. Endocrinology 2016, 157, 679-691. [CrossRef] [PubMed]

68. Zhang, L.N.; Mitchell, S.E.; Hambly, C.; Morgan, D.G.; Clapham, J.C.; Speakman, J.R. Physiological and behavioral responses to intermittent starvation in C57BL/6J mice. Physiol. Behav. 2012, 105, 376-387. [CrossRef]

69. Kalra, S.P.; Kalra, P.S. Neuropeptide Y: A physiological orexigen modulated by the feedback action of ghrelin and leptin. Endocrine 2003, 22, 49-56. [CrossRef]

70. Finch, G.M.; Day, J.E.; Razak; Welch, D.A.; Rogers, P.J. Appetite changes under free-living conditions during Ramadan fasting. Appetite 1998, 31, 159-170. [CrossRef]

71. Thivel, D.; Finlayson, G.; Miguet, M.; Pereira, B.; Duclos, M.; Boirie, Y.; Doucet, E.; Blundell, J.E.; Metz, L. Energy depletion by 24-h fast leads to compensatory appetite responses compared with matched energy depletion by exercise in healthy young males. Br. J. Nutr. 2018, 1-10. [CrossRef]

72. Clayton, D.J.; Burrell, K.; Mynott, G.; Creese, M.; Skidmore, N.; Stensel, D.J.; James, L.J. Effect of 24-h severe energy restriction on appetite regulation and ad libitum energy intake in lean men and women. Am. J. Clin. Nutr. 2016, 104, 1545-1553. [CrossRef]

73. Karbowska, J.; Kochan, Z. Intermittent fasting up-regulates Fsp27/Cidec gene expression in white adipose tissue. Nutrition 2012, 28, 294-299. [CrossRef] [PubMed]

74. Malafaia, A.B.; Nassif, P.A.; Ribas, C.A.; Ariede, B.L.; Sue, K.N.; Cruz, M.A. Obesity induction with high fat sucrose in rats. Arq. Bras. Cir. Dig. 2013, 26, 17-21. [CrossRef] [PubMed]

75. Lasheen, N.N. Pancreatic functions in high salt fed female rats. Physiol. Rep. 2015, 3. [CrossRef] [PubMed]

76. Carter, S.; Clifton, P.M.; Keogh, J.B. The effects of intermittent compared to continuous energy restriction on glycaemic control in type 2 diabetes; a pragmatic pilot trial. Diabetes Res. Clin. Pract. 2016, 122, 106-112. [CrossRef] [PubMed]

77. Joslin, P.M.N.; Bell, R.K.; Swoap, S.J. Obese mice on a high-fat alternate-day fasting regimen lose weight and improve glucose tolerance. J. Anim. Physiol. Anim. Nutr. 2017, 101, 1036-1045. [CrossRef] [PubMed]

78. Costill, D.L.; Hargreaves, M. Carbohydrate nutrition and fatigue. Sports Med. 1992, 13, 86-92. [CrossRef] [PubMed]

79. Alsubheen, S.A.; Ismail, M.; Baker, A.; Blair, J.; Adebayo, A.; Kelly, L.; Chandurkar, V.; Cheema, S.; Joanisse, D.R.; Basset, F.A. The effects of diurnal Ramadan fasting on energy expenditure and substrate oxidation in healthy men. Br. J. Nutr. 2017, 118, 1023-1030. [CrossRef] 
80. Moro, T.; Tinsley, G.; Bianco, A.; Marcolin, G.; Pacelli, Q.F.; Battaglia, G.; Palma, A.; Gentil, P.; Neri, M.; Paoli, A. Effects of eight weeks of time-restricted feeding (16/8) on basal metabolism, maximal strength, body composition, inflammation, and cardiovascular risk factors in resistance-trained males. J. Transl. Med. 2016, 14, 290. [CrossRef]

81. Norouzy, A.; Salehi, M.; Philippou, E.; Arabi, H.; Shiva, F.; Mehrnoosh, S.; Mohajeri, S.M.; Mohajeri, S.A.; Motaghedi Larijani, A.; Nematy, M. Effect of fasting in Ramadan on body composition and nutritional intake: A prospective study. J. Hum. Nutr. Diet 2013, 97-104. [CrossRef]

82. Yarahmadi, S.; Larijani, B.; Bastanhagh, M.H.; Pajouhi, M.; Baradar Jalili, R.; Zahedi, F.; Zendehdel, K.; Akrami, S.M. Metabolic and clinical effects of Ramadan fasting in patients with type II diabetes. J. Coll. Physicians Surg. Pak. 2003, 13, 329-332.

83. Liu, H.; Javaheri, A.; Godar, R.J.; Murphy, J.; Ma, X.; Rohatgi, N.; Mahadevan, J.; Hyrc, K.; Saftig, P.; Marshall, C.; et al. Intermittent fasting preserves beta-cell mass in obesity-induced diabetes via the autophagy-lysosome pathway. Autophagy 2017, 13, 1952-1968. [CrossRef] [PubMed]

84. Park, S.; Yoo, K.M.; Hyun, J.S.; Kang, S. Intermittent fasting reduces body fat but exacerbates hepatic insulin resistance in young rats regardless of high protein and fat diets. J. Nutr. Biochem. 2017, 40, 14-22. [CrossRef] [PubMed]

85. Zhao, T.J.; Liang, G.; Li, R.L.; Xie, X.; Sleeman, M.W.; Murphy, A.J.; Valenzuela, D.M.; Yancopoulos, G.D.; Goldstein, J.L.; Brown, M.S. Ghrelin O-acyltransferase (GOAT) is essential for growth hormone-mediated survival of calorie-restricted mice. Proc. Natl. Acad. Sci. USA 2010, 107, 7467-7472. [CrossRef] [PubMed]

86. Sangiao-Alvarellos, S.; Cordido, F. Effect of ghrelin on glucose-insulin homeostasis: Therapeutic implications. Int. J. Pept. 2010, 2010. [CrossRef] [PubMed]

87. Antunes, L.A.C.; Jornada, M.N.; Elkfury, J.L.; Foletto, K.C.; Bertoluci, M.C. Fasting ghrelin but not PYY(3-36) is associated with insulin-resistance independently of body weight in Wistar rats. Arq. Bras. Endocrinol. Metabol. 2014, 58, 377-381. [CrossRef] [PubMed]

88. Barazzoni, R.; Zanetti, M.; Cattin, M.R.; Visintin, L.; Vinci, P.; Cattin, L.; Stebel, M.; Guarnieri, G. Ghrelin enhances in vivo skeletal muscle but not liver AKT signaling in rats. Obesity 2007, 15, 2614-2623. [CrossRef] [PubMed]

89. Cerqueira, F.M.; da Cunha, F.M.; Caldeira da Silva, C.C.; Chausse, B.; Romano, R.L.; Garcia, C.C.; Colepicolo, P.; Medeiros, M.H.; Kowaltowski, A.J. Long-term intermittent feeding, but not caloric restriction, leads to redox imbalance, insulin receptor nitration, and glucose intolerance. Free Radic. Biol. Med. 2011, 51, 1454-1460. [CrossRef]

90. Rosas Fernández, M.A.; Concha Vilca, C.M.; Batista, L.O.; Ramos, V.W.; Cinelli, L.P.; Tibau de Albuquerque, K. Intermittent food restriction in female rats induces SREBP high expression in hypothalamus and immediately postfasting hyperphagia. Nutrition 2017, 48, 122-126. [CrossRef]

91. Marangou, A.G.; Weber, K.M.; Boston, R.C.; Aitken, P.M.; Heggie, J.C.; Kirsner, R.L.; Best, J.D.; Alford, F.P. Metabolic consequences of prolonged hyperinsulinemia in humans. Evidence for induction of insulin insensitivity. Diabetes 1986, 35, 1383-1389. [CrossRef]

92. Del Prato, S.; Leonetti, F.; Simonson, D.C.; Sheehan, P.; Matsuda, M.; DeFronzo, R.A. Effect of sustained physiologic hyperinsulinaemia and hyperglycaemia on insulin secretion and insulin sensitivity in man. Diabetologia 1994, 37, 1025-1035. [CrossRef]

93. Koopmans, S.J.; Ohman, L.; Haywood, J.R.; Mandarino, L.J.; DeFronzo, R.A. Seven days of euglycemic hyperinsulinemia induces insulin resistance for glucose metabolism but not hypertension, elevated catecholamine levels, or increased sodium retention in conscious normal rats. Diabetes 1997, 46, 1572-1578. [CrossRef] [PubMed]

94. Bertacca, A.; Ciccarone, A.; Cecchetti, P.; Vianello, B.; Laurenza, I.; Maffei, M.; Chiellini, C.; Del Prato, S.; Benzi, L. Continually high insulin levels impair Akt phosphorylation and glucose transport in human myoblasts. Metabolism 2005, 54, 1687-1693. [CrossRef]

95. Bertacca, A.; Ciccarone, A.; Cecchetti, P.; Vianello, B.; Laurenza, I.; Del Prato, S.; Benzi, L. High insulin levels impair intracellular receptor trafficking in human cultured myoblasts. Diabetes Res. Clin. Pract. 2007, 78, 316-323. [CrossRef] [PubMed]

96. Kim, B.; McLean, L.L.; Philip, S.S.; Feldman, E.L. Hyperinsulinemia induces insulin resistance in dorsal root ganglion neurons. Endocrinology 2011, 152, 3638-3647. [CrossRef] [PubMed] 
97. Catalano, K.J.; Maddux, B.A.; Szary, J.; Youngren, J.F.; Goldfine, I.D.; Schaufele, F. Insulin resistance induced by hyperinsulinemia coincides with a persistent alteration at the insulin receptor tyrosine kinase domain. PLoS ONE 2014, 9, e108693. [CrossRef] [PubMed]

98. Genuth, S.M.; Przybylski, R.J.; Rosenberg, D.M. Insulin resistance in genetically obese, hyperglycemic mice. Endocrinology 1971, 88, 1230-1238. [CrossRef]

99. Odeleye, O.E.; de Courten, M.; Pettitt, D.J.; Ravussin, E. Fasting hyperinsulinemia is a predictor of increased body weight gain and obesity in Pima Indian children. Diabetes 1997, 46, 1341-1345. [CrossRef]

100. Sigal, R.J.; El-Hashimy, M.; Martin, B.C.; Soeldner, J.S.; Krolewski, A.S.; Warram, J.H. Acute postchallenge hyperinsulinemia predicts weight gain: A prospective study. Diabetes 1997, 46, 1025-1029. [CrossRef]

101. Ishikawa, M.; Pruneda, M.L.; Adams-Huet, B.; Raskin, P. Obesity-independent hyperinsulinemia in nondiabetic first-degree relatives of individuals with type 2 diabetes. Diabetes 1998, 47, 788-792. [CrossRef]

102. Mehran, A.E.; Templeman, N.M.; Brigidi, G.S.; Lim, G.E.; Chu, K.Y.; Hu, X.; Botezelli, J.D.; Asadi, A.; Hoffman, B.G.; Kieffer, T.J.; et al. Hyperinsulinemia drives diet-induced obesity independently of brain insulin production. Cell Metab. 2012, 16, 723-737. [CrossRef]

103. Templeman, N.M.; Clee, S.M.; Johnson, J.D. Suppression of hyperinsulinaemia in growing female mice provides long-term protection against obesity. Diabetologia 2015, 58, 2392-2402. [CrossRef] [PubMed]

104. Reaven, G.M.; Hoffman, B.B. A role for insulin in the aetiology and course of hypertension? Lancet 1987, 2, 435-437. [CrossRef]

105. Takatori, S.; Zamami, Y.; Mio, M.; Kurosaki, Y.; Kawasaki, H. Chronic hyperinsulinemia enhances adrenergic vasoconstriction and decreases calcitonin gene-related peptide-containing nerve-mediated vasodilation in pithed rats. Hypertens. Res. 2006, 29, 361-368. [CrossRef] [PubMed]

106. Zamami, Y.; Takatori, S.; Hobara, N.; Yabumae, N.; Tangsucharit, P.; Jin, X.; Hashikawa, N.; Kitamura, Y.; Sasaki, K.; Kawasaki, H. Hyperinsulinemia induces hypertension associated with neurogenic vascular dysfunction resulting from abnormal perivascular innervations in rat mesenteric resistance arteries. Hypertens. Res. 2011, 34, 1190-1196. [CrossRef] [PubMed]

107. Nakamura, A.; Monma, Y.; Kajitani, S.; Noda, K.; Nakajima, S.; Endo, H.; Takahashi, T.; Nozaki, E. Effect of glycemic state on postprandial hyperlipidemia and hyperinsulinemia in patients with coronary artery disease. Heart Vessels 2015. [CrossRef] [PubMed]

108. Zidi, W.; Allal-Elasmi, M.; Zayani, Y.; Zaroui, A.; Guizani, I.; Feki, M.; Mourali, M.S.; Mechmeche, R.; Kaabachi, N. Metabolic Syndrome, Independent Predictor for Coronary Artery Disease. Clin. Lab. 2015, 61, 1545-1552. [CrossRef] [PubMed]

109. Madonna, R.; De Caterina, R. Prolonged exposure to high insulin impairs the endothelial PI3-kinase/Akt/nitric oxide signalling. Thromb. Haemost. 2009, 101, 345-350. [CrossRef]

110. Steneberg, P.; Rubins, N.; Bartoov-Shifman, R.; Walker, M.D.; Edlund, H. The FFA receptor GPR40 links hyperinsulinemia, hepatic steatosis, and impaired glucose homeostasis in mouse. Cell Metab. 2005, 1, 245-258. [CrossRef]

111. Bril, F.; Lomonaco, R.; Orsak, B.; Ortiz-Lopez, C.; Webb, A.; Tio, F.; Hecht, J.; Cusi, K. Relationship between disease severity, hyperinsulinemia, and impaired insulin clearance in patients with nonalcoholic steatohepatitis. Hepatology 2014, 59, 2178-2187. [CrossRef]

112. Westermark, P.; Wilander, E. The influence of amyloid deposits on the islet volume in maturity onset diabetes mellitus. Diabetologia 1978, 15, 417-421. [CrossRef]

113. Bonner-Weir, S. Regulation of pancreatic beta-cell mass in vivo. Recent Prog. Horm. Res. 1994, 49, 91-104. [PubMed]

114. Butler, A.E.; Janson, J.; Bonner-Weir, S.; Ritzel, R.; Rizza, R.A.; Butler, P.C. Beta-cell deficit and increased beta-cell apoptosis in humans with type 2 diabetes. Diabetes 2003, 52, 102-110. [CrossRef] [PubMed]

115. Kasuga, M. Insulin resistance and pancreatic beta cell failure. J. Clin. Investig. 2006, 116, 1756-1760. [CrossRef] [PubMed]

116. Király, M.A.; Bates, H.E.; Kaniuk, N.A.; Yue, J.T.; Brumell, J.H.; Matthews, S.G.; Riddell, M.C.; Vranic, M. Swim training prevents hyperglycemia in ZDF rats: Mechanisms involved in the partial maintenance of beta-cell function. Am. J. Physiol. Endocrinol. Metab. 2008, 294, E271-E283. [CrossRef] [PubMed]

117. Karaca, M.; Magnan, C.; Kargar, C. Functional pancreatic beta-cell mass: Involvement in type 2 diabetes and therapeutic intervention. Diabetes Metab. 2009, 35, 77-84. [CrossRef] [PubMed]

118. Cerf, M.E. Beta cell dysfunction and insulin resistance. Front. Endocrinol. 2013, 4, 37. [CrossRef] 
119. Sies, H. Oxidative stress: From basic research to clinical application. Am. J. Med. 1991, 91, 31S-38S. [CrossRef]

120. Halliwell, B.; Cross, C.E. Oxygen-derived species: Their relation to human disease and environmental stress. Environ. Health Perspect. 1994, 102, 5-12.

121. Vincent, A.M.; Brownlee, M.; Russell, J.W. Oxidative stress and programmed cell death in diabetic neuropathy. Ann. N. Y. Acad. Sci. 2002, 959, 368-383. [CrossRef]

122. Loh, K.P.; Huang, S.H.; De Silva, R.; Tan, B.K.; Zhu, Y.Z. Oxidative stress: Apoptosis in neuronal injury. Curr. Alzheimer Res. 2006, 3, 327-337. [CrossRef]

123. Ryter, S.W.; Kim, H.P.; Hoetzel, A.; Park, J.W.; Nakahira, K.; Wang, X.; Choi, A.M. Mechanisms of cell death in oxidative stress. Antioxid. Redox Signal. 2007, 9, 49-89. [CrossRef] [PubMed]

124. Choi, K.; Kim, J.; Kim, G.W.; Choi, C. Oxidative stress-induced necrotic cell death via mitochondira-dependent burst of reactive oxygen species. Curr. Neurovasc. Res. 2009, 6, 213-222. [CrossRef] [PubMed]

125. Navarro-Yepes, J.; Burns, M.; Anandhan, A.; Khalimonchuk, O.; del Razo, L.M.; Quintanilla-Vega, B.; Pappa, A.; Panayiotidis, M.I.; Franco, R. Oxidative stress, redox signaling, and autophagy: Cell death versus survival. Antioxid. Redox Signal. 2014, 21, 66-85. [CrossRef] [PubMed]

126. Filomeni, G.; De Zio, D.; Cecconi, F. Oxidative stress and autophagy: The clash between damage and metabolic needs. Cell Death Differ. 2015, 22, 377-388. [CrossRef] [PubMed]

127. Zraika, S.; Hull, R.L.; Udayasankar, J.; Aston-Mourney, K.; Subramanian, S.L.; Kisilevsky, R.; Szarek, W.A.; Kahn, S.E. Oxidative stress is induced by islet amyloid formation and time-dependently mediates amyloid-induced beta cell apoptosis. Diabetologia 2009, 52, 626-635. [CrossRef]

128. Lee, B.W.; Chae, H.Y.; Kwon, S.J.; Park, S.Y.; Ihm, J.; Ihm, S.H. RAGE ligands induce apoptotic cell death of pancreatic $\beta$-cells via oxidative stress. Int. J. Mol. Med. 2010, 26, 813-818.

129. Lu, T.H.; Su, C.C.; Chen, Y.W.; Yang, C.Y.; Wu, C.C.; Hung, D.Z.; Chen, C.H.; Cheng, P.W.; Liu, S.H.; Huang, C.F. Arsenic induces pancreatic $\beta$-cell apoptosis via the oxidative stress-regulated mitochondria-dependent and endoplasmic reticulum stress-triggered signaling pathways. Toxicol. Lett. 2011, 201, 15-26. [CrossRef]

130. Chen, K.L.; Liu, S.H.; Su, C.C.; Yen, C.C.; Yang, C.Y.; Lee, K.I.; Tang, F.C.; Chen, Y.W.; Lu, T.H.; Su, Y.C.; et al. Mercuric compounds induce pancreatic islets dysfunction and apoptosis in vivo. Int. J. Mol. Sci. 2012, 13, 12349-12366. [CrossRef]

131. Du, S.C.; Ge, Q.M.; Lin, N.; Dong, Y.; Su, Q. ROS-mediated lipopolysaccharide-induced apoptosis in INS-1 cells by modulation of Bcl-2 and Bax. Cell Mol. Biol. 2012, 58, OL1654-9.

132. Chang, K.C.; Hsu, C.C.; Liu, S.H.; Su, C.C.; Yen, C.C.; Lee, M.J.; Chen, K.L.; Ho, T.J.; Hung, D.Z.; Wu, C.C.; et al. Cadmium induces apoptosis in pancreatic $\beta$-cells through a mitochondria-dependent pathway: The role of oxidative stress-mediated c-Jun N-terminal kinase activation. PLoS ONE 2013, 8, e54374. [CrossRef]

133. Tachibana, K.; Sakurai, K.; Yokoh, H.; Ishibashi, T.; Ishikawa, K.; Shirasawa, T.; Yokote, K. Mutation in insulin receptor attenuates oxidative stress and apoptosis in pancreatic beta-cells induced by nutrition excess: Reduced insulin signaling and ROS. Horm. Metab. Res. 2015, 47, 176-183. [CrossRef] [PubMed]

134. Johnson, J.D.; Bernal-Mizrachi, E.; Alejandro, E.U.; Han, Z.; Kalynyak, T.B.; Li, H.; Beith, J.L.; Gross, J.; Warnock, G.L.; Townsend, R.R.; et al. Insulin protects islets from apoptosis via Pdx1 and specific changes in the human islet proteome. Proc. Natl. Acad. Sci. USA 2006, 103, 19575-19580. [CrossRef] [PubMed]

135. Beith, J.L.; Alejandro, E.U.; Johnson, J.D. Insulin stimulates primary beta-cell proliferation via Raf-1 kinase. Endocrinology 2008, 149, 2251-2260. [CrossRef] [PubMed]

136. Carlson, O.; Martin, B.; Stote, K.S.; Golden, E.; Maudsley, S.; Najjar, S.S.; Ferrucci, L.; Ingram, D.K.; Longo, D.L.; Rumpler, W.V.; et al. Impact of reduced meal frequency without caloric restriction on glucose regulation in healthy, normal-weight middle-aged men and women. Metabolism 2007, 56, 1729-1734. [CrossRef]

137. Oishi, K.; Hashimoto, C. Short-term time-restricted feeding during the resting phase is sufficient to induce leptin resistance that contributes to development of obesity and metabolic disorders in mice. Chronobiol. Int. 2018, 1-19. [CrossRef]

138. Cote, I.; Toklu, H.Z.; Green, S.M.; Morgan, D.; Carter, C.S.; Tumer, N.; Scarpace, P.J. Limiting feeding to the active phase reduces blood pressure without the necessity of caloric reduction or fat mass loss. Am. J. Physiol. Regul. Integr. Comp. Physiol. 2018. [CrossRef]

139. Woodie, L.N.; Luo, Y.; Wayne, M.J.; Graff, E.C.; Ahmed, B.; O’Neill, A.M.; Greene, M.W. Restricted feeding for $9 \mathrm{~h}$ in the active period partially abrogates the detrimental metabolic effects of a Western diet with liquid sugar consumption in mice. Metabolism 2018, 82, 1-13. [CrossRef] 
140. Bi, H.; Gan, Y.; Yang, C.; Chen, Y.; Tong, X.; Lu, Z. Breakfast skipping and the risk of type 2 diabetes: A meta-analysis of observational studies. Public Health Nutr. 2015, 18, 3013-3019. [CrossRef]

141. Reutrakul, S.; Hood, M.M.; Crowley, S.J.; Morgan, M.K.; Teodori, M.; Knutson, K.L. The relationship between breakfast skipping, chronotype, and glycemic control in type 2 diabetes. Chronobiol. Int. 2014, 31, 64-71. [CrossRef]

142. Azami, Y.; Funakoshi, M.; Matsumoto, H.; Ikota, A.; Ito, K.; Okimoto, H.; Shimizu, N.; Tsujimura, F.; Fukuda, H.; Miyagi, C.; et al. Long working hours and skipping breakfast concomitant with late evening meals are associated with suboptimal glycemic control among young male Japanese patients with type 2 diabetes. J. Diabetes Investig. 2018. [CrossRef]

143. Watanabe, Y.; Saito, I.; Henmi, I.; Yoshimura, K.; Maruyama, K.; Yamauchi, K.; Matsuo, T.; Kato, T.; Tanigawa, T.; Kishida, T.; et al. Skipping Breakfast is Correlated with Obesity. J. Rural Med. 2014, 9, 51-58. [CrossRef] [PubMed]

144. Sakurai, M.; Yoshita, K.; Nakamura, K.; Miura, K.; Takamura, T.; Nagasawa, S.Y.; Morikawa, Y.; Kido, T.; Naruse, Y.; Nogawa, K.; et al. Skipping breakfast and 5-year changes in body mass index and waist circumference in Japanese men and women. Obes. Sci. Pract. 2017, 3, 162-170. [CrossRef] [PubMed]

145. Uemura, M.; Yatsuya, H.; Hilawe, E.H.; Li, Y.; Wang, C.; Chiang, C.; Otsuka, R.; Toyoshima, H.; Tamakoshi, K.; Aoyama, A. Breakfast Skipping is Positively Associated with Incidence of Type 2 Diabetes Mellitus: Evidence From the Aichi Workers' Cohort Study. J. Epidemiol. 2015, 25, 351-358. [CrossRef] [PubMed]

146. Møller, N.; Jørgensen, J.O. Effects of growth hormone on glucose, lipid, and protein metabolism in human subjects. Endocr. Rev. 2009, 30, 152-177. [CrossRef] [PubMed]

(C) 2020 by the authors. Licensee MDPI, Basel, Switzerland. This article is an open access article distributed under the terms and conditions of the Creative Commons Attribution (CC BY) license (http://creativecommons.org/licenses/by/4.0/). 